\title{
Lappeenranta
}

University of Technology

Heikki Särkkä

\section{ELECTRO-OXIDATION TREATMENT OF PULP AND PAPER MILL CIRCULATING WATERS AND WASTEWATERS}

Thesis for the degree of Doctor of Science (Technology) to be presented with due permission for public examination and criticism in the Auditorium in MUC, Mikkeli University Consortium, Mikkeli, Finland on the 30th of July, 2013 at noon.

Acta Universitatis

Lappeenrantaensis 524 
Supervisor

Reviewers

Opponent
Prof. Mika Sillanpää

Lappeenranta University of Technology

Laboratory of Green Chemistry

Mikkeli, Finland

Prof. Jeyong Yoon

Seoul National University

School of Chemical and Biological Engineering

College of Engineering

Republic of Korea

Prof. Enric Brillas Coso

Universitat de Barcelona

Departament de Química Física

Spain

Prof. Guohua Chen

The Hong Kong University of Science and Technology

Department of Chemical and Biomolecular Engineering (CBME)

Hong Kong

China

ISBN 978-952-265-431-1

ISBN 978-952-265-432-8 (PDF)

ISSN-L 1456-4491

ISSN 1456-4491

Lappeenrannan teknillinen yliopisto

Yliopistopaino 2013 


\author{
ABSTRACT \\ Heikki Särkkä \\ Electro-Oxidation Treatment of Pulp and Paper Mill Circulating Waters and Wastewaters \\ Lappeenranta 2013 \\ p. 96 \\ Acta Universitatis Lappeenrantaensis 524 \\ Diss. Lappeenrannan teknillinen yliopisto \\ ISBN 978-952-265-431-1, ISBN 978-952-265-432-8 (PDF), ISSN-L 1456-4491, ISSN 1456-4491
}

Interest in water treatment by electrochemical methods has grown in recent years. Electrochemical oxidation has been applied particularly successfully to degrade different organic pollutants and disinfect drinking water.

This study summarizes the effectiveness of the electrochemical oxidation technique in inactivating different primary biofilm forming paper mill bacteria as well as sulphide and organic material in pulp and paper mill wastewater in laboratory scale batch experiments. Three different electrodes, borondoped diamond (BDD), mixed metal oxide (MMO) and $\mathrm{PbO}_{2}$, were employed as anodes. The impact on inactivation efficiency of parameters such as current density and initial $\mathrm{pH}$ or chloride concentration of synthetic paper machine water was studied. The electrochemical behaviour of the electrodes was investigated by cyclic voltammetry with $\mathrm{MMO}, \mathrm{BDD}$ and $\mathrm{PbO}_{2}$ electrodes in synthetic paper mill water as also with MMO and stainless steel electrodes with biocides. Some suggestions on the formation of different oxidants and oxidation mechanisms were also presented during the treatment.

Aerobic paper mill bacteria species (Deinococcus geothermalis, Pseudoxanthomonas taiwanensis and Meiothermus silvanus) were inactivated effectively ( $>2 \mathrm{log}$ ) at MMO electrodes by current density of $50 \mathrm{~mA} / \mathrm{cm}^{2}$ and the time taken three minutes. Increasing current density and initial chloride concentration of paper mill water increased the inactivation rate of Deinococcus geothermalis. The inactivation order of different bacteria species was Meiothermus silvanus $>$ Pseudoxanthomonas taiwanensis $>$ Deinococcus geothermalis. It was observed that inactivation was mainly due to the electrochemically generated chlorine/hypochlorite from chloride present in the water and also residual disinfection by chlorine/hypochlorite occurred.

In real paper mill effluent treatment sulphide oxidation was effective with all the different initial concentrations (almost 100\% reduction, current density $42.9 \mathrm{~mA} / \mathrm{cm}^{2}$ ) and also anaerobic bacteria inactivation was observed (almost $90 \%$ reduction by chloride concentration of $164 \mathrm{mg} / \mathrm{L}$ and current density of $42.9 \mathrm{~mA} / \mathrm{cm}^{2}$ in five minutes). Organic material removal was not as effective when comparing with other tested techniques, probably due to the relatively low treatment times.

Cyclic voltammograms in synthetic paper mill water with stainless steel electrode showed that $\mathrm{H}_{2} \mathrm{O}_{2}$ could be degraded to radicals during the cathodic runs. This emphasises strong potential of combined electrochemical treatment with this biocide in bacteria inactivation in paper mill environments. 
The results of the experiments showed that electrochemical oxidation could be used in paper mill waters for planktonic bacteria removal. Applying this technique together with some biocides can enhance the oxidation process, keeping the paper mill pipelines clean of slime formed by bacteria. Electrochemical oxidation is also a promising preliminary or tertiary treatment process in pulp and paper mill wastewater treatment, especially against refractory organic compounds which cannot be removed by biological processes.

Keywords: electrochemical oxidation, electrode, hydroxyl radical, hypochlorite, biocides, biofouling, cyclic voltammogram, hydrogen peroxide, pulp and paper mill wastewater

UDC 676.088:628.3.034.2:66.087.3:628.349:676 


\section{ACKNOWLEDGEMENTS}

First of all, I would like to thank my supervisor Prof. Mika Sillanpää for his support and encouragement to finish my thesis over these eight years. His ambitious attitude to research work has also motivated me a lot during my studies. I really want to thank him for giving me this opportunity in his well-equipped laboratory.

I also want to thank Mr. Martti Pulliainen from Savcor Forest Oy for numerous discussions regarding my work, his helpful knowledge of electrochemistry and other support. Also Dr. Technol. Mikko Vepsäläinen helped me a great deal with his excellent ideas regarding my work and positive attitude even when I experienced some difficult moments. Thanks, Mikko!

I express my sincerely gratitude to Professor Enric Brillas and Professor Jeyong Yoon for reviewing my thesis and for their valuable comments and improvement suggestions regarding the thesis.

The financial support of Savcor Forest Oy, The City of Mikkeli, The European Union and The Regional Council of South Savo is highly appreciated.

I also want to thank all my colleagues in our laboratory over these years. I have met people whose knowledge and attitude to research work still surprise me every day. I have had hours of fascinating and intense discussions about my research and life in general with many of you and I have learnt many things about life from you. I want to name Liza, Tuan, Dekey, Antti and Juha in particular; you are very good friends. In general, it has been a great honour and opportunity for me to meet new friends from around the world in our very international laboratory.

Finally, I want to thank my family, relatives and friends for their support and patience in my studies. I have been lucky to have so many caring people around me who have helped me in many things in my life and supported me to achieve this goal. I will never forget them.

In Mikkeli 24.6.2013, 



\section{LIST OF PUBLICATIONS}

The publications are listed in roman numerals in the text as follows:

I. Heikki Särkkä, Mikko Vepsäläinen, Martti Pulliainen, Mika Sillanpää, Inactivation of Deinococcus geothermalis Bacteria in Synthetic Paper Machine Water by Electrochemical Oxidation. Journal of Pulp and Paper Science 33 (2007) 95-99.

II. Heikki Särkkä, Mikko Vepsäläinen, Martti Pulliainen, Mika Sillanpää, Electrochemical inactivation of paper mill bacteria with mixed metal oxide electrode. Journal of Hazardous Materials 156 (2008) 208-213.

III. Heikki Särkkä, Kaisa Kuhmonen, Mikko Vepsäläinen, Martti Pulliainen, Jukka Selin, Pekka Rantala, Esko Kukkamäki, Mika Sillanpää, Electrochemical oxidation of sulphides in paper mill wastewater by using mixed oxide anodes. Environmental Technology 30 (2009) 885-892.

IV. Heikki Särkkä, Marko Kolari, Martti Pulliainen, Mika Sillanpää, Potential Generation of Oxidizing Radicals in Synthetic Paper Mill Water by Electrochemical Treatment Combined with Biocides. Current Organic Chemistry 16 (2012) 2054-2059.

V. Minghua Zhou, Heikki Särkkä, Mika Sillanpää, A comparative experimental study on methyl orange degradation by electrochemical oxidation on BDD and MMO electrodes. Separation and Purification Technology 78 (2011) 290-297.

VI. Kati Eskelinen, Heikki Särkkä, Tonni Agustiono Kurniawan, Mika E.T. Sillanpää, Removal of recalcitrant contaminants from bleaching effluents in pulp and paper mills using ultrasonic irradiation and Fenton-like oxidation, electrochemical treatment, and/or chemical precipitation: A comparative study. Desalination 255 (2010) 179-187. 


\section{Author's contribution to publications I-IV}

Planned and designed experiments with other co-authors, carried out all the experiments, analysed the data, interpreted the results and prepared the first draft of all the manuscripts.

\section{Author's contribution to publications V-VI}

Participated in planning and designing experiments related to electrochemical oxidation part, participated in analysing the data, interpreting the results and commented the drafts of the manuscripts. 


\section{TABLE OF CONTENTS}

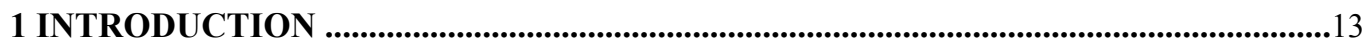

1.1. Pulp and paper mill circulating waters and wastewaters .......................................................13

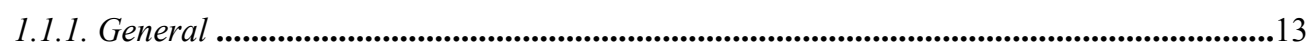

1.1.2. Micro-organisms in the paper mill environment ..................................................................13

1.2. Wastewater treatment in the pulp and paper mills ..................................................................15

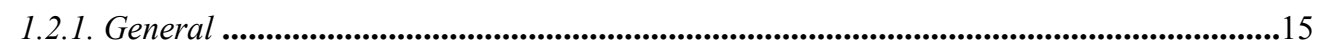

1.2.2. Primary and secondary treatment ............................................................................................. 17

1.2.3. Tertiary treatment ..........................................................................................................18

1.3. Electrochemical oxidation in water and wastewater treatment ........................................21

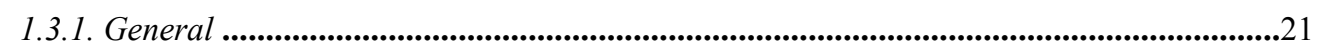

1.3.2. Theory of electro-oxidation …......................................................................................23

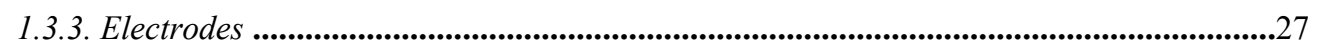

1.3.4. Treatment of different wastewaters ......................................................................................31

1.3.5. Disinfection of wastewater and drinking water ....................................................................36

2 OBJECTIVES OF THE STUDY …............................................................................................41

3 MATERIALS AND METHODS ..................................................................................43

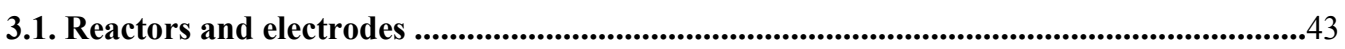

3.2. Chemicals ........................................................................................................................4

3.2.1. Wastewaters used for the experiments .......................................................................46

3.2.2. Biocides...................................................................................................................................50

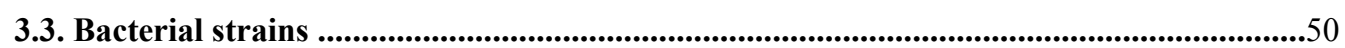

3.4. Analyses .................................................................................................................................

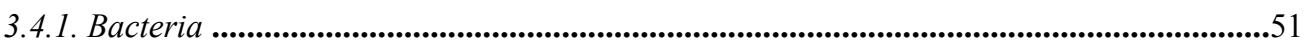

3.4.2. Oxidants..............................................................................................................................

3.4.3. Cyclic voltammograms .......................................................................................51

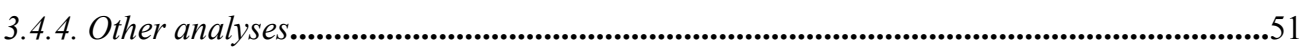

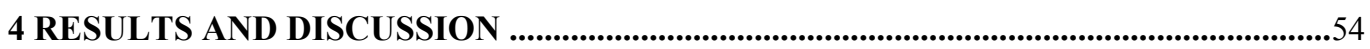

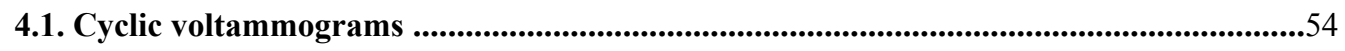

4.2. Electrochemical inactivation of bacteria ……….........................................................58 
4.2.1. Aerobic bacteria in synthetic paper mill water .....................................................................58

4.2.2. Anaerobic bacteria in paper mill wastewater .....................................................................68

4.3. Electrochemical oxidation of sulphide ..................................................................69

4.4. Electrochemical oxidation of organics in pulp and paper mill bleaching effluent ...........71

4.5. Electrochemical degradation of methyl orange dye ...................................................71

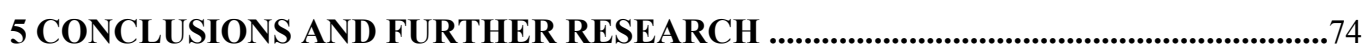

\section{REFERENCES}




\section{List of symbols}

$\begin{array}{ll}\mathrm{HO}_{2}{ }^{*} & \text { perhydroxyl radical } \\ \mathrm{I} & \text { current } \\ \mathrm{M} & \text { electrode surface } \\ { }^{*} \mathrm{OH} & \text { hydroxyl radical } \\ \mathrm{R} & \text { organic pollutant } \\ \mathrm{t} & \text { time }\end{array}$

Abbreviations

$\begin{array}{ll}\text { AOP } & \text { advanced oxidation processes } \\ \text { AOX } & \text { adsorbable organic halides } \\ \text { APC } & \text { aerobic plate count } \\ \text { BDD } & \text { boron-doped diamond } \\ \text { BOD } & \text { biological oxygen demand } \\ \text { BSTFA } & \text { bis(trimethylsilyl)trifluroacetamide } \\ \text { CEH } & \text { chlorination, extraction and hypochlorite bleaching } \\ \text { CFU } & \text { colony forming unit } \\ \text { COD } & \text { chemical oxygen demand } \\ \text { CV } & \text { cyclic voltammogram } \\ \text { DAF } & \text { dissolved air flotation } \\ \text { DO } & \text { dissolved oxygen } \\ \text { DOC } & \text { dissolved organic carbon } \\ \text { DSA } & \text { dimensionally stable anodes } \\ \text { EC } & \text { electrocoagulation } \\ \text { EF } & \text { electroflotation } \\ \text { EO } & \text { electro-oxidation }\end{array}$




\begin{tabular}{|c|c|}
\hline GC & gas chromatograph \\
\hline GCE & general current efficiency \\
\hline HFCVD & hot filament chemical vapor deposition \\
\hline MB & methylene blue \\
\hline MF & microfiltration \\
\hline MMO & mixed metal oxide \\
\hline MO & methyl orange \\
\hline MS & mass selective \\
\hline MTBE & methyl tert-butyl ether \\
\hline NF & nanofiltration \\
\hline NOM & natural organic matter \\
\hline PAM & polyacrylamide \\
\hline PCA & plate count agar \\
\hline RO & reverse osmosis \\
\hline ROS & reactive oxygen species \\
\hline RSM & response surface methodology \\
\hline SCE & saturated calomel electrode \\
\hline SEM & scanning electron microscope \\
\hline SHE & standard hydrogen electrode \\
\hline SPEF & solar photoelectro-Fenton \\
\hline SPW & synthetic paper mill water \\
\hline SS & stainless steel \\
\hline TCF & totally chlorine free \\
\hline TMCS & trimethylchlorosilane \\
\hline TOC & total organic carbon \\
\hline UF & ultrafiltration \\
\hline UV & ultraviolet \\
\hline
\end{tabular}




\section{INTRODUCTION}

\subsection{Pulp and paper mill circulating waters and wastewaters}

\subsubsection{General}

The pulp and paper industry, like the primary metal and chemical industries, uses a great deal of raw water [1]. Water is needed at paper mills mainly for the pulp washing procedure and paper forming process in the wet end phase. Modern mills need 15 to $50 \mathrm{~m}^{3}$ of water to produce a ton of paper or cardboard $[1,2]$ and consumption varies depending on the manufacturing process and country.

Pulp and paper mill circulating waters and wastewaters are a very complex mixture of different organic and inorganic compounds. Wastewaters from pulp making mainly contain lignin, resin acids, fatty acids and dissolved wood extractives [3-5]. After pulp bleaching inorganic chlorine and AOX compounds may also be present, depending on the bleaching procedure [4]. The wastewater generated from the paper making process contains particulate waste, organic compounds (e.g. fatty and resin acids), anions, inorganic dyes and biocides [6-9]. These substances can be highly toxic in natural waters causing fish death and negatively affecting the whole ecosystem [3].

\subsubsection{Micro-organisms in the paper mill environment}

A recent trend is the circulation of process waters, and purified wastewater may even be used again in the paper making process. Recycling of these waters is important to utilize as much fibers as possible in paper sheet making process [6]. This can reduce fresh water consumption but introduce other challenges, such as the neutralization of cationic retention chemicals, corrosion problems and the biofouling of pipelines by microbes. Biofouling is usually prevented by using chemicals (biocides), which are often relatively toxic to handle and the risk of negative effects in the receiving waters is 
increased after wastewater treatment [6]. Some biocides can also retain in fibers and accumulate in the final paper product.

Because of the nutrient-rich, moist and warm paper mill environment, many microbes exist in paper mill circulating waters. Micro-organisms are constantly introduced into paper machines through raw materials, water, fibres and paper-making chemicals [10-12]. Microbial growth, if not controlled, can result in slime formation which can seriously disturb the paper making process and have a negative impact on the quality of the paper [11]. Free-living bacteria are not a major problem (some degrade fibre, for example), but when these species attach to the pipelines creating floccules or slime, the process is easily disturbed, causing breaks in the paper web [12]. Attached bacteria growing on a surface as a biofilm are not easy to remove by physical means such as washing. Mechanical cleaning is also a common method, though switching off the paper machine for cleaning the pipelines causes financial losses. Thus the paper industry uses biocides to control excessive bacterial growth $[6,12,13,14]$. Biocides are usually classified as either oxidizing or non-oxidizing and chlorine, hydrogen peroxide and peracetic acid are examples of oxidizing species used in mills.

Paper mill microbe communities vary a lot depending on the mill and paper making process used. Direct microscopic examination of slime deposits shows microbes with different shapes and sizes [11]. Filamentous organisms can be fungi or bacteria which are capable of accumulating large amounts of colourful slime. Many species have been isolated in these environments, such as Deinococcus, Pseudoxanthomonas, Meiothermus and Bacillus [12,14,15]. Väisänen et al. [12] isolated totally 390 strains of aerobic bacteria from printing paper machines. Deinococcus geothermalis was one of the species that could adhere to stainless steel surface only within one day. It is known for forming firm colored biofilms and for its persistence against cleaning and chemical treatments [13]. Some of these species can attach firmly to the surface of the pipelines and sometimes further species can attach to these, speeding up the biofouling process $[16,17]$. In favourable 
conditions, microbes can also produce odorous and toxic compounds such as $\mathrm{H}_{2} \mathrm{~S}$ or cause localized corrosion under the biofilm deposits. Many strains also degrade paper-making raw materials, such as fibers and chemicals.

\subsection{Wastewater treatment in the pulp and paper mills}

\subsubsection{General}

The wastewater produced during paper-making process has to be purified before piping into natural waters or recycling back into process. The quality of the wastewater varies significantly depending on the processes and chemicals used for pulp and paper making operations. Some wastewater quality parameters for various pulp and paper processes are presented in Table 1 [3]. It can be concluded that the variation between wastewater parameters is significant in different processes, increasing the challenges for wastewater treatment processes at mills. 
Table 1. Characteristics of wastewater at various pulp and paper processes [adapted from reference 3].

\begin{tabular}{|c|c|c|c|c|c|c|c|}
\hline \multirow[t]{2}{*}{ Process } & \multicolumn{6}{|c|}{ Parameters } & \multirow[t]{2}{*}{ Ref. } \\
\hline & pH & $\begin{array}{c}\text { TS } \\
(\mathrm{mg} / \mathrm{L})\end{array}$ & $\begin{array}{c}\mathrm{SS} \\
(\mathrm{mg} / \mathrm{L})\end{array}$ & $\begin{array}{l}\text { BOD }_{5} \\
(\mathrm{mg} / \mathrm{L})\end{array}$ & $\begin{array}{c}\text { COD } \\
(\mathrm{mg} / \mathrm{L})\end{array}$ & $\begin{array}{l}\text { Colour } \\
\text { (Pt-Co) }\end{array}$ & \\
\hline Kraft mill & 8.2 & 8260 & 3620 & - & 4112 & 4667.5 & [18] \\
\hline $\begin{array}{l}\text { Bleached pulp } \\
\text { mill }\end{array}$ & 7.5 & - & 1133 & 1566 & 2572 & 4033 & [19] \\
\hline Pulp and paper & 7.8 & 4200 & 1400 & 1050 & 4870 & $\begin{array}{c}\text { Dark } \\
\text { Brown }\end{array}$ & [20] \\
\hline Paper making & 7.8 & 1844 & 760 & 561 & 953 & Black & [21] \\
\hline Paper mill & 8.7 & 2415 & 935 & 425 & 845 & $\begin{array}{c}\text { Dark } \\
\text { Brown }\end{array}$ & [22] \\
\hline Paper machine & 4.5 & - & 503 & 170 & 723 & 243 & [19] \\
\hline
\end{tabular}

The main treatment process used at pulp and paper mills is primary clarification followed by biological treatment (secondary treatment). A tertiary process is needed e.g. for removing recalcitrant organic compounds or colour before water is circulated again into the process or to rivers or lakes (Fig. 1) [1]. Primary clarification can be achieved by either settlement or flotation, secondary 
treatment by aerobic or anaerobic biological treatment and tertiary treatment for example by membrane processes, advanced oxidation processes or coagulation/flocculation.

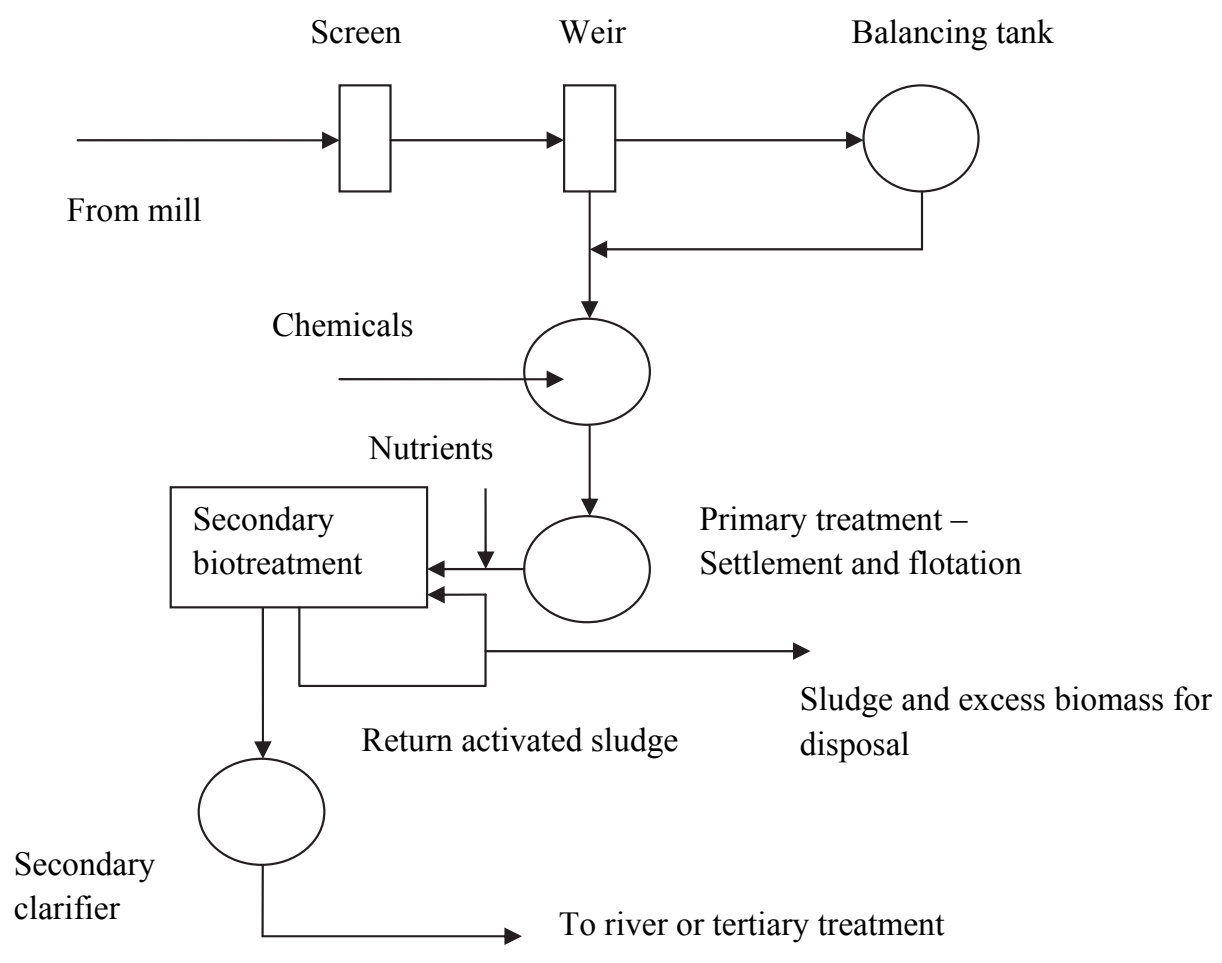

Figure 1. Generalized schematic diagram of the plant for the treatment of paper mill effluent [adapted from reference 1]

\subsubsection{Primary and secondary treatment}

Sedimentation units usually achieve high removal rates for suspended solids, but little organic material (BOD and COD) is eliminated [1]. Flotation is also used for the removal of suspended solids [3]. Recently electrochemical techniques such as electroflotation (EF) have been applied in industrial 
wastewater effluents as a primary or tertiary treatment [23,24]. Ben Mansour et al. [24] reported that the purification efficiency of suspended solids by combined coagulation/electroflotation process exceeded $95 \%$.

Aerobic treatment is still the most popular secondary treatment technique for the removal of soluble biodegradable organic pollutants from pulp and paper mill effluents. There are numerous aerobic biological treatment systems available, but the most common is the activated sludge process, which can achieve high removal efficiencies for BOD and COD [1,3]. This process has certain disadvantages however, such as the production of sludges with very variable settlement properties, sensitivity to shock loading and toxicity, and limited capacity to remove poorly biodegradable toxic substances.

An anaerobic process has potential advantages over aerobic treatment, such as lower sludge production and chemical consumption [1]. It also produces methane which can be used for energy production. It also has its limitations, including potential hydrogen sulphide production in pulp and paper mill effluents due to the high sulphur content of wastewaters.

\subsubsection{Tertiary treatment}

Tertiary treatment of pulp and paper mill wastewaters is often needed to reach the target limit values set by the authorities for the further removal of residual COD, toxicity, colour and micro-organisms. Membrane-based techniques, advanced oxidation processes and physico-chemical processes are often used for this purpose $[1,3]$.

Among the advanced treatment processes, membrane technology offers an alternative [25]. Membrane techniques include microfiltration (MF), ultrafiltration (UF), nanofiltration (NF) and reverse osmosis (RO). Pizzichini et al. [26] pilot scale tested these techniques to remove salts, COD and total organic carbon (TOC) from the paper mill wastewater. MF followed by RO filtration could 
recycle more than $80 \%$ of the original wastewater back into paper making process. Beril Gönder et al. [25] found out that biologically treated pulp and paper mill wastewater could be used again as process water using two-step NF. UF removed metals from totally chlorine free (TCF) wastewater and the process was enhanced by adding water-soluble polymeric ligands [27].

Chemical coagulation using alum, ferric chloride, ferric sulphate and lime have been used extensively in the treatment of different wastewaters [28]. Interest in the use of synthetic polyelectrolytes as flocculants for pulp mill wastewater treatment has grown recently [29]. The main advantage of polymeric flocculants is their ability to produce large, dense, compact and stronger floccules with good settling characteristics compared to those obtained by coagulation alone [28]. In particular polyacrylamide (PAM) flocculants have been used intensively in pulp and paper mill effluent treatment and proved their economic feasibility [28,29]. Coagulation/flocculation treatment can also be combined successfully with other techniques, such as heterogeneous photocatalysis [30].

Adsorption of organic pollutants from pulp and paper mill effluents is an alternative technique. Zhang and Chuang [31] compared the performance of styrene divinylbenzene copolymer and activated carbon for the acidic bleach plant effluent treatment. It was observed that resin is more effective than activated carbon in colour removal and that it is possible to regenerate resin by washing with sodium hydroxide solution.

Advanced oxidation processes (AOPs) for wastewater treatment have received significant attention in recent years. AOPs are based on the generation of very reactive non-selective oxidizing species such as the hydroxyl radicals [32]. These radicals can be formed by combining the following oxidizing agents: ozone $\left(\mathrm{O}_{3}\right)$, hydrogen peroxide $\left(\mathrm{H}_{2} \mathrm{O}_{2}\right)$, ultraviolet (UV) radiation, ferrous and ferric salts $\left(\mathrm{Fe}^{2+}\right.$ and $\left.\mathrm{Fe}^{3+}\right)$ and catalysts such as $\mathrm{TiO}_{2}$. Catalkaya and Kargi [32,33] utilized these techniques in combination or individually to purify pulp mill effluents from colour, TOC and AOX compounds. 
The results showed that $\mathrm{TiO}_{2}$-assisted photocatalysis $\left(\mathrm{UV} / \mathrm{TiO}_{2}\right)$ achieved the highest $\mathrm{TOC}$ and toxicity removals [32] and in another study [33] Fenton's reagent utilizing $\mathrm{H}_{2} \mathrm{O}_{2} / \mathrm{Fe}^{2+}$ resulted in the highest colour, TOC and AOX removals under acidic conditions compared to the other AOP's tested. Solar photocatalysis [34] with Fenton reagent and $\mathrm{TiO}_{2}$ and solar photo-Fenton [35] reactions have also been shown to be effective in the removal of refractory, organic compounds.

Catalysed ozonation has demonstrated promising results compared to conventional ozonation treatment. Homogeneous and heterogeneous catalysts have been used for the treatment of pulp and paper mill effluents [36,37]. Activated carbon together with ozonation treatment could increase the $\mathrm{BOD}_{5} / \mathrm{COD}$ ratio from 0.11 to 0.28 and $87 \%$ of colour was removed from chlorination, extraction and hypochlorite $(\mathrm{CEH})$ bleaching effluent [36]. Fontanier et al. [37] used TOCCATA ${ }^{\circledR}$ catalyst in treating three different wastewaters from pulp and paper mills. It was shown that organic matter was removed through the steady conversion of organic carbon to carbon dioxide. Ozonation has also been applied to NF concentrate to increase its biodegradability [38].

Electrochemical techniques have been applied recently in pulp and paper mill wastewater treatment. Vepsäläinen et al. [39] investigated natural organic matter (NOM) removal by electrocoagulation (EC) together with chemical coagulation. The results indicated that the combined method was efficient in removing NOM even with small electric charges per litre. EC has also yielded promising results in sulphide and toxic pollutant removal from pulp and paper mill effluents [40,41].

Though several pulp and paper mill wastewater treatment techniques are available, many of these are still associated with high investment and running costs or lack of efficiency to remove refractory organic pollutants from effluents. It is important to maximize purification efficiencies and develop new, simple in situ techniques for treating pulp and paper mill effluents and circulating waters. 
Strategies that promote lower energy use, reduce the amount of solid waste produced and increase efficient energy recovery are economically sustainable [42].

\subsection{Electrochemical oxidation in water and wastewater treatment}

\subsubsection{General}

Electrochemical techniques have been applied extensively to treat various wastewaters, disinfect drinking water or enhance polluted soils [43-52]. These include e.g. EC, EF, EO and electrokinetic treatment. Conventional water purification techniques, such as chemical coagulation, biological treatment or UV oxidation, are not effective against some toxic and refractory organic pollutants. Electrochemical techniques can offer a more efficient means of treating these pollutants.

Electrochemical techniques are innovative, inexpensive and effective methods for purifying wastewaters from many industrial processes before discharge into water systems or circulation back into processes [44]. They could also be called "green technology" methods because little or no chemicals are needed to facilitate water treatment. Electrochemical techniques can also be applied in sludge treatment. Tuan et al. [46] wrote a review about applying electro-dewatering to sewage sludge treatment. It was found that electro-dewatering has several potential benefits, such as lower energy and transportation costs and enhanced solid-liquid separation of sludge. Yet high operation costs still hinder the use of electro-dewatering in large scale applications.

Electrokinetic Fenton process is a promising technology for the remediation of low permeable soil $[47,48]$. It is effective for highly biorefractory contaminants, such as hexachlorobenzene. It is important to optimize parameters such as $\mathrm{pH}$ level at the cathode region or contact between the contaminant and the oxidant during the treatment, however $[47,48]$. 
Ultrasonically enhanced electrokinetics can increase pollutant removal from soils $[49,50]$. It has several advantages, such as lack of dangerous breakdown products and compact and transportable onsite treatment. Yet it still has technical limitations such as scaling up and physical effects such as noise.

EC is currently enjoying both increased popularity and major technical improvement [44]. It is a rather simple and robust technique and can be applied in many environments. However, it involves several chemical and physical phenomena which should be well understood before effective treatment. When "sacrificial" iron and aluminium anodes are releasing ions into water, EF occurs simultaneously by hydrogen and oxygen bubbles released at the electrodes, improving purification efficiency. Disadvantages of EC are the periodical need for replacement of anodes, electrode passivation and the lack of any systematic approach to reactor design and operation [45].

An important factor in EF treatment is the size of bubbles formed at the electrodes [43]. Smaller bubbles are more efficient in pollutant removal because of the larger surface area available for particle attachment. EF is a promising technique especially in oily wastewater treatment and it shows advantages over either DAF or settling.

EO treatment has received a great deal of interest in wastewater treatment and drinking water disinfection in recent years [43]. The technique is rather simple. Oxidants are produced during the treatment in situ either at the electrodes or indirectly by chemical compounds in the treated water. Unfortunately the lack of efficient and stable yet economical electrode material has hindered the large scale application of this technique to date. 


\subsubsection{Theory of electro-oxidation}

Thermodynamically, the electrochemical degradation of any soluble organic compound in water should be achieved at low potentials, before the thermodynamic potential of water oxidation to molecular oxygen (1.23 V/SHE under standard conditions) as indicated in formula 1 [53]:

$2 \mathrm{H}_{2} \mathrm{O} \rightarrow \mathrm{O}_{2}+4 \mathrm{H}^{+}+4 \mathrm{e}^{-}$

In acidic media, water can be discharged on the electrode producing highly oxidative absorbed hydroxyl radicals (reaction 2):

$\mathrm{H}_{2} \mathrm{O}+\mathrm{M} \rightarrow \mathrm{M}\left({ }^{*} \mathrm{OH}\right)+\mathrm{H}^{+}+\mathrm{e}^{-}$

where M means electrode surface.

These radicals are physisorbed on the anode surface where the organic pollutant $\mathrm{R}$ can be oxidized as follows (reaction 3):

$\mathrm{R}_{(\mathrm{aq})}+\mathrm{M}\left({ }^{*} \mathrm{OH}\right)_{n / 2} \rightarrow \mathrm{M}+$ Oxidation products $+\frac{n}{2} \mathrm{H}^{+}+\frac{n}{2} \mathrm{e}^{-}$,

where $n$ is the number of electrons involved in the oxidation reaction of R. The reaction of organics with electrogenerated hydroxyl radicals (3) is in competition with the side reaction of the anodic discharge of these radicals to oxygen (reaction 4):

$\mathrm{M}\left({ }^{*} \mathrm{OH}\right) \rightarrow \mathrm{M}+\frac{1}{2} \mathrm{O}_{2}+\mathrm{H}^{+}+\mathrm{e}^{-}$

Anodic activity by electrodes depends on their value of overpotential for oxygen evolution [43]. Platinum electrodes have much lower potential value for oxygen evolution reactions (1.3 V vs. SHE) than for example $\mathrm{SnO}_{2}$ electrodes (1.9 V vs. SHE) or boron-doped diamond electrodes (Ti/BDD, 2.7 V vs. SHE). This signifies that anodic oxidation by hydroxyl radicals can take place on a Ti/BDD 
electrode surface at a significantly higher current density with a minimal oxygen evolution side reaction.

Electrochemical oxidation may also occur by an indirect process where oxidants like chlorine, hypochlorous acid and hypochlorite [54-60] or hydrogen peroxide/ozone [61-64] are formed at electrodes by following reactions (5-11):

$2 \mathrm{Cl}^{-} \rightarrow \mathrm{Cl}_{2}+2 \mathrm{e}^{-}$

$\mathrm{Cl}_{2}+\mathrm{H}_{2} \mathrm{O} \rightarrow \mathrm{HOCl}+\mathrm{H}^{+}+\mathrm{Cl}^{-}$

$\mathrm{HOCl} \rightarrow \mathrm{H}^{+}+\mathrm{OCl}^{-}$

$\mathrm{H}_{2} \mathrm{O} \rightarrow{ }^{*} \mathrm{OH}+\mathrm{H}^{+}+\mathrm{e}^{-}$

$2{ }^{*} \mathrm{OH} \rightarrow \mathrm{H}_{2} \mathrm{O}_{2}$

$\mathrm{H}_{2} \mathrm{O}_{2} \rightarrow \mathrm{O}_{2}+2 \mathrm{H}^{+}+2 \mathrm{e}^{-}$

$\mathrm{O}_{2}+{ }^{*} \mathrm{O} \rightarrow \mathrm{O}_{3}$

At acidic $\mathrm{pH}$, chlorine is present in the solution in the form of hypochlorous acid, which has a higher oxidation potential $(1.49 \mathrm{~V})$ than hypochlorite $(0.94 \mathrm{~V})$. Under alkaline conditions hypochlorite is a dominant species [55]. Under higher $\mathrm{pH}$ conditions more chlorate or perchlorate is also formed instead of chlorine/hypochlorite, which decreases oxidation efficiency. Higher initial chloride concentration in the electrolyte solution naturally encourages more chlorine/hypochlorite production [54-56]. A similar effect can be observed by lowering the temperature of the electrolyte solution, but this depends on the electrode material used [56]. Higher current density also increases chlorine production $[55,56]$. 
Electrochemical production of reactive oxygen species (ROS) such as ozone and hydrogen peroxide has proved effective in water disinfection without the mediation of active chlorine products [61]. In an electro-Fenton oxidation process, $\mathrm{H}_{2} \mathrm{O}_{2}$ is continuously generated in acidic solutions by the reduction of $\mathrm{O}_{2}$ at the graphite cathodes or carbon felt [62]. When $\mathrm{Fe}^{2+}$ is introduced as the catalyst, a Fenton reaction takes place in the solution, generating hydroxyl radicals to decompose pollutants or disinfect bacteria. Chu et al. [63] recognized effective degradation of 4-nitrophenol by employing a dual-cathode system to generate $\mathrm{H}_{2} \mathrm{O}_{2}$ and $\mathrm{Fe}^{2+}$ simultaneously at two cathodes to encourage an electro-Fenton reaction in the solution together with anodic oxidation by hydroxyl radicals at the anode. Guinea et al. [64] achieved almost total mineralization of enrofloxacin solutions by solar photoelectro-Fenton (SPEF) treatment using an $\mathrm{O}_{2}$-diffusion cathode. Some examples of indirect electro-oxidation studies are shown in Table 2.

Efficient organic pollutant removal can be achieved also by generating $\mathrm{Fe}^{2+}$ in situ by an EC process where an iron anode is dissolved into a solution, causing a Fenton reaction when hydrogen peroxide is added to the solution $[65,66]$. Martins et al. [65] could remove $95 \%$ of nonylphenol polyethoxylate in five minutes (aqueous solution) and in ten minutes (wastewater), respectively. 
Table 2. Indirect electro-oxidation of pollutants

\begin{tabular}{|c|c|c|c|c|c|c|}
\hline Matrix & Pollutant & Anode material & $\begin{array}{l}\text { Removal } \\
\text { efficiency }\end{array}$ & Main oxidant & $\begin{array}{l}\text { Current } \\
\text { density } \\
\left(\mathbf{m A} / \mathbf{c m}^{2}\right)\end{array}$ & Ref. \\
\hline $\begin{array}{l}\text { Synthetic } \\
\text { dye } \\
\text { wastewater }\end{array}$ & Colour & $\begin{array}{l}\text { Dimensionally } \\
\text { stable anode } \\
\text { (DSA) }\end{array}$ & $100 \%$ & Chlorine/hypochlorite & 36.1 & [54] \\
\hline $\begin{array}{l}\text { Synthetic } \\
\text { dye } \\
\text { wastewater }\end{array}$ & Colour & DSA & $100 \%$ & Chlorine/hypochlorite & $\begin{array}{l}14.44- \\
36.10\end{array}$ & [55] \\
\hline $\begin{array}{l}\text { Synthetic } \\
\text { water }\end{array}$ & - & $\mathrm{IrO}_{2}-\mathrm{Ta}_{2} \mathrm{O}_{5}$ & - & Chlorine/hypochlorite & 15 & {$[56]$} \\
\hline $\begin{array}{l}\text { Synthetic } \\
\text { water }\end{array}$ & - & $\mathrm{IrO}_{2} / \mathrm{RuO}_{2}$ & - & Chlorine/hypochlorite & 30 & {$[57]$} \\
\hline $\begin{array}{l}\text { Synthetic } \\
\text { dye } \\
\text { wastewater }\end{array}$ & Colour & $\begin{array}{l}\text { Ti anode covered } \\
\text { by Ta, Pt and Ir } \\
\text { thin film }\end{array}$ & $100 \%$ & Chlorine/hypochlorite & $\begin{array}{l}5,10,14 \\
\text { and } 20 \mathrm{~A}\end{array}$ & [58] \\
\hline $\begin{array}{l}\text { Synthetic } \\
\text { dye } \\
\text { wastewater }\end{array}$ & Colour & $\mathrm{Nb} / \mathrm{D}$ and $\mathrm{Pt} / \mathrm{Ti}$ & $\begin{array}{l}\text { up to } 90 \\
\%\end{array}$ & Chlorine/hypochlorite & $\begin{array}{l}12-18 \mathrm{~V} \\
\text { (anode } \\
\text { potential) }\end{array}$ & [59] \\
\hline $\begin{array}{l}\text { Olive oil } \\
\text { wastewater }\end{array}$ & $\begin{array}{l}\text { Phenol, } \\
\text { colour }\end{array}$ & $\begin{array}{l}\text { Ti anode covered } \\
\text { by Ta, Pt and Ir } \\
\text { thin film }\end{array}$ & $\begin{array}{l}\text { Almost } \\
100 \%\end{array}$ & Chlorine/hypochlorite & $\begin{array}{l}5,7 \text { and } 9 \\
\mathrm{~V} \text { (cell } \\
\text { potential) }\end{array}$ & [60] \\
\hline $\begin{array}{l}\text { Synthetic } \\
\text { water }\end{array}$ & E. Coli & BDD & $\begin{array}{l}\text { under } \\
\text { detection } \\
\text { limit }\end{array}$ & $\begin{array}{l}\text { Ozone, hydrogen } \\
\text { peroxide }\end{array}$ & $1.5-13.3$ & [61] \\
\hline $\begin{array}{l}\text { Synthetic } \\
\text { water }\end{array}$ & $\begin{array}{l}\text { Rotenone } \\
\text { (COD } \\
\text { removal) }\end{array}$ & Pt net & $>97 \%$ & $\begin{array}{l}\text { Hydrogen peroxide } \\
\text { (EF) }\end{array}$ & $10-60$ & [62] \\
\hline
\end{tabular}


Table contd.

\begin{tabular}{|c|c|c|c|c|c|c|}
\hline Matrix & Pollutant & Anode material & $\begin{array}{l}\text { Removal } \\
\text { efficiency }\end{array}$ & Main oxidant & $\begin{array}{l}\text { Current } \\
\text { density } \\
\left(\mathrm{mA} / \mathrm{cm}^{2}\right)\end{array}$ & Ref. \\
\hline $\begin{array}{l}\text { Synthetic } \\
\text { water }\end{array}$ & $\begin{array}{l}\text { 4- } \\
\text { nitrophenol } \\
\text { (TOC } \\
\text { removal) }\end{array}$ & $\begin{array}{l}\mathrm{Ti} / \mathrm{SnO}_{2}-\mathrm{Sb}_{2} \mathrm{O}_{5^{-}} \\
\mathrm{IrO}_{2}\end{array}$ & $74.5 \%$ & $\begin{array}{l}\text { Hydrogen peroxide } \\
\text { (EF) }\end{array}$ & $\begin{array}{l}-0.80 \text { and } \\
-0.10 \\
\text { V/SCE }\end{array}$ & [63] \\
\hline $\begin{array}{l}\text { Synthetic } \\
\text { water }\end{array}$ & $\begin{array}{l}\text { Fluoroquino } \\
\text { lone } \\
\text { enrofloxacin } \\
\text { (TOC } \\
\text { removal) }\end{array}$ & $\begin{array}{l}\text { Pt sheet and } \\
\text { BDD thin film }\end{array}$ & $\begin{array}{l}\text { Almost } \\
100 \%\end{array}$ & $\begin{array}{l}\text { Hydrogen peroxide } \\
\text { (SPEF) }\end{array}$ & 33 & [64] \\
\hline
\end{tabular}

\subsubsection{Electrodes}

Several electrodes have been used for water treatment by electrochemical oxidation. Anodes used for water and wastewater treatment include lead and lead dioxide [67-70], DSA electrodes [71-74], graphite [75-77] and boron-doped diamond electrodes [70,78-85].

Lead and lead dioxide have been used as anodes because of their stability, low cost and high oxygen evolution potential which delays $\mathrm{O}_{2}$ evolution in favour of $\mathrm{Cl}_{2}$ evolution [67]. Hamza et al. [68] completely mineralized of 1,3,5-trimethoxybenzene in acid media at a $\mathrm{Ta} / \mathrm{PbO}_{2}$ anode. They discovered that all oxidation products were finally oxidized to $\mathrm{CO}_{2}$ by the intermediary of carboxylic acids. Awad and Abo Galwa [69] found out that the electrocatalytic activity of a lead dioxide electrode depends on the conductive electrolyte. They concluded that in the presence of $\mathrm{H}_{2} \mathrm{SO}_{4}$ electrolyte electrode poisoning occurred, since an adherent film was formed on the anode surface. The dissolution of toxic $\mathrm{Pb}^{2+}$ ions also hinders the use of lead and lead dioxide as anodes [43]. 
DSA are catalytic oxide electrodes which can effectively generate active hydroxyl radicals and active chloride species [72]. They also have a relatively high overpotential for oxygen evolution. Efficient degradation of paper mill wastewater was achieved using three-dimensional electrodes $\left(\mathrm{Ti} / \mathrm{Co} / \mathrm{SnO}_{2}-\right.$ $\mathrm{Sb}_{2} \mathrm{O}_{5}$ ) combined with activated carbon treatment [72]. This was mainly due to the fact that the conversion rate within an electrochemical reactor can be increased substantially due to its large specific surface area in comparison to conventional two-dimensional electrodes. So-called "nonactive" electrodes such as $\mathrm{SnO}_{2}$ form hydroxyl radicals on their surface more easily, which can result in the complete oxidation of the organic molecules to $\mathrm{CO}_{2}$ [74]. With "active electrodes", such as $\mathrm{RuO}_{2}$ and $\mathrm{IrO}_{2}$, only selective oxidation of the organic species in the solution occurs.

Effective removal of COD (>96\%) was achieved when the electrochemical degradation process was catalysed by transition metals ( $\mathrm{Co}$ and $\mathrm{Cu}$ ) [76] or molybdenum and phosphate (Mo-P) modified kaolin with graphite as the anode and cathode [77]. Pollutants were adsorbed on the surface of the kaolin where they were oxidized by hydroxyl radicals produced at the graphite cathode by the reaction of hydrogen peroxide and transition metals [76]. This process is similar to the electro-Fenton process.

Recently the potential of conducting diamond films for water treatment has been recognised. They have an inert surface with low adsorption properties, remarkable corrosion stability even in strong acidic media and an extremely wide potential window in aqueous and non-aqueous media $[79,81]$. They also have the highest oxygen evolution overpotential value $[43,79]$ meaning that more hydroxyl radicals are formed on the anode surface during treatment. BDD electrodes can also degrade refractory organic pollutants completely and the nature of the pollutant does not affect the efficiency of the process significantly [80]. It is also known that besides hydroxyl radical formation on the electrode surface, diamond electrodes also increase mediated oxidation by other electrochemically 
formed compounds such as persulphate, perphosphate, percarbonate or hypochlorite depending on the electrolyte used.

The low pressure conversion of carbon to diamond crystals has made it possible to grow a thin layer of diamond film on suitable substrates such as silicon, niobium, tungsten, molybdenum, and titanium [82]. Hot filament chemical vapour deposition (HFCVD) technique has been applied primarily to fabricate active and stable BDD electrodes, mainly using titanium as a substrate material $[82,84,85]$. Migliorini et al. [85] used an additional $\mathrm{H}_{2}$ gas flux passing through a bubbler containing a solution of $\mathrm{B}_{2} \mathrm{O}_{3}$ dissolved in $\mathrm{CH}_{3} \mathrm{OH}$ with a $\mathrm{B} / \mathrm{C}$ ratio of $30,000 \mathrm{ppm}$ during the HFCVD coating of diamond films. Two different fluxes were used to produce heavily boron-doped diamond films. Figure 2 shows the top view of scanning electron microscope (SEM) images of the deposited diamond films. The images present well-facetted microcrystalline diamond surfaces for both coatings and a significant increase in the smallest diamond grain population for E2 because as the boron content increases, the diamond grain size decreases.
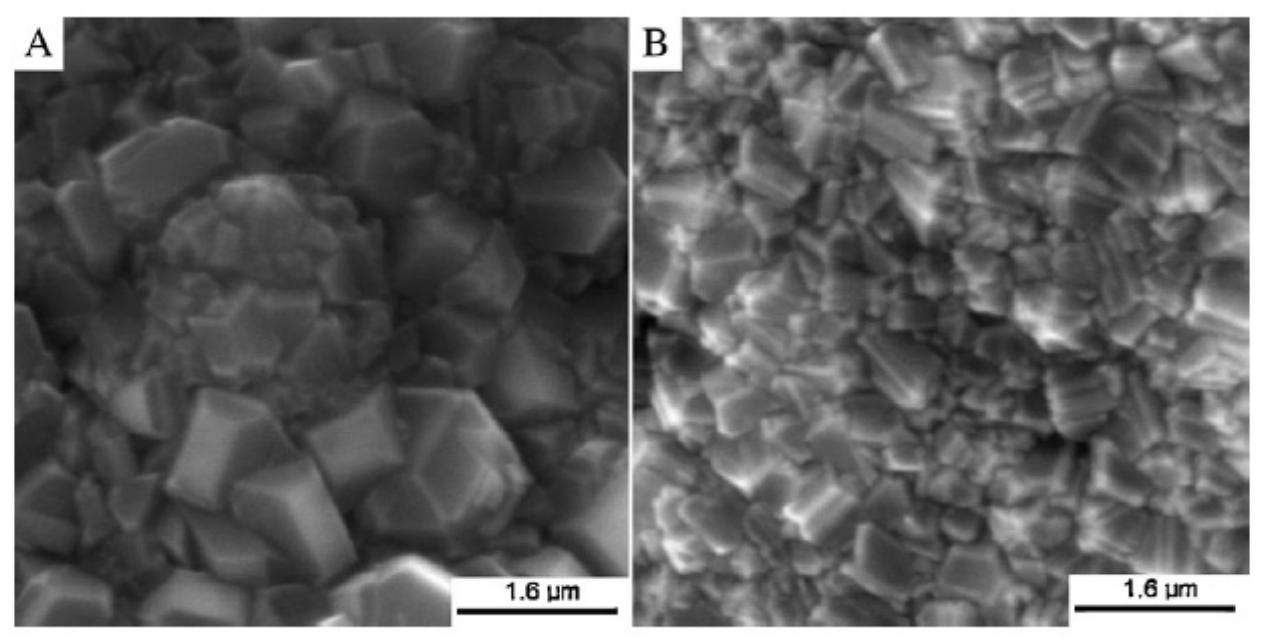

Figure 2. SEM images of E1 and E2 BDD films [85] 
The main advantages and disadvantages of different electrodes in EO treatment are presented in Table

3.

Table 3. Comparison of electrodes in EO treatment

\begin{tabular}{|c|c|c|c|}
\hline Electrode & Advantages & Disadvantages & Compared to other electrodes \\
\hline $\mathrm{Ti}$ & Stable & Passive, expensive & \\
\hline $\mathrm{Pt}$ & $\begin{array}{l}\text { Inert, low oxygen } \\
\text { evolution } \\
\text { overpotential }\end{array}$ & Expensive & $\begin{array}{l}\text { Poor efficiency in anodic oxidation } \\
\text { of organic compounds }\end{array}$ \\
\hline $\mathrm{PbO}_{2}$ & $\begin{array}{l}\text { Good current } \\
\text { efficiency, cheap, } \\
\text { effective in } \\
\text { oxidizing pollutants, } \\
\text { high oxygen } \\
\text { evolution } \\
\text { overpotential, easy } \\
\text { to prepare }\end{array}$ & $\begin{array}{l}\text { Corrosive, toxic } \\
\mathrm{Pb}^{2+} \text {-ions could be } \\
\text { released }\end{array}$ & \\
\hline DSA electrodes & $\begin{array}{l}\text { Supports indirect } \\
\text { oxidation, good } \\
\text { current efficiency, } \\
\text { high oxygen } \\
\text { evolution } \\
\text { overpotential, lower } \\
\text { cost, higher } \\
\text { availability }\end{array}$ & $\begin{array}{l}\text { Short lifetime, lack } \\
\text { of electrochemical } \\
\text { stability }\end{array}$ & \\
\hline BDD & $\begin{array}{l}\text { Inert in tough } \\
\text { conditions, high } \\
\text { oxygen evolution } \\
\text { overpotential and } \\
\text { electrochemical } \\
\text { stability, good } \\
\text { current efficiency, } \\
\text { high corrosion } \\
\text { stability, good } \\
\text { conductivity }\end{array}$ & Very expensive & Higher activity \\
\hline
\end{tabular}




\subsubsection{Treatment of different wastewaters}

EO treatment has been applied in various wastewaters. The treatment of highly refractory dyes has yielded especially promising results [86-89]. Ma et al. [86] found out that $96.47 \%$ of COD could be removed from methylene blue (MB) containing wastewater assisted by $\mathrm{Fe}_{2} \mathrm{O}_{3}$-modified kaolin with graphite plate electrodes. The performances of the Ti-Pt/ $\beta-\mathrm{PbO}_{2}$ and $\mathrm{BDD}$ electrodes were investigated in Reactive Orange 16 dye treatment [87]. Total decolourisation was achieved by both electrodes but BDD electrode was more effective with lower energy consumption. A study by Tsantaki et al. [88] showed that complete decolourisation of textile dyehouse effluents was achieved by BDD electrodes in 180 minutes. Song et al. [89] observed that the decolouring efficiency of the azo dye C.I. Reactive Red 195 increased whereas the mineralization efficiency decreased with increasing concentrations of $\mathrm{NaCl}$ signifying that oxidized active chlorine at the anode favours the oxidation cleavage of the azo bond.

Ramirez et al. [90] degraded methyl orange azo dye in a recirculation flow plant system. BDD electrodes gave an optimum decolourization efficiency of about $94 \%$ with a flow rate of $12 \mathrm{~L} / \mathrm{min}$ and response surface methodology (RSM) was used to describe the EO treatment behaviour.

Coupling ozone and EO treatment significantly improved COD removal from industrial wastewater [91]. The coupled process was efficient at a relatively low current density so the synergistic effect was easily recognized. Xu et al. [92] and Park et al. [93] presented the innovative approach of combining membrane filtration techniques such as NF and MF with EO treatment. It was observed that the concentration polarization and membrane fouling were effectively restrained by electroosmosis, electrophoresis and EO treatment [92]. During electrochemical degradation of municipal wastewater the simultaneous production of hydrogen fuel was observed [93]. MF after EO 
treatment achieved significant TOC and turbidity removals, with a clear reduction in membrane fouling.

EO treatment together with biological oxidation was investigated in individual, combined and integrated methods [94]. It was observed that the combined process performed rather better than the individual, but took longer. It was concluded that combined processes can be improved by optimizing process parameters and experimental design. A study by Gonçalves et al. [95] presented the positive performance of a two-step process consisting of anaerobic digestion followed by EO in olive mill wastewater treatment.

A novel catalyst prepared by Chen et al. [96] showed excellent catalytic activity in the electrochemical treatment of 1-naphthylamine wastewater. Kinetic experiments with EO resulted in the complete removal of iohexol and showed great agreement between the experimental results and the kinetic model [97].

EO treatment of reverse osmosis concentrate revealed that in the presence of high chloride ions concentrations of persistent halogenated by-products will be formed [98]. Another study by Bagastyo et al. [99] showed that effective dissolved organic carbon (DOC) removal could be achieved without chlorine mediated oxidation and by-products. Toxic by-products hinder the use of the EO technique in wastewater treatment and other water purification techniques are needed for removing by-products before water will be recycled back into the process or released into natural waters.

Some comparison in the treatment of different wastewaters and pollutants has been presented in Table 4. 
Table 4. EO treatment of different pollutants

\begin{tabular}{|c|c|c|c|c|c|}
\hline Matrix & Pollutant & Electrodes & $\begin{array}{l}\text { Removal } \\
\text { efficiency }\end{array}$ & $\begin{array}{l}\text { Current } \\
\text { densities used } \\
\left(\mathbf{m A} / \mathbf{c m}^{2}\right)\end{array}$ & Ref. \\
\hline $\begin{array}{l}\text { Synthetic dye } \\
\text { wastewater }\end{array}$ & COD & Graphite & $96.47 \%$ & 69.23 & {$[86]$} \\
\hline $\begin{array}{l}\text { Synthetic dye } \\
\text { wastewater }\end{array}$ & Colour & $\begin{array}{l}\mathrm{Ti}-\mathrm{Pt} / \beta-\mathrm{PbO}_{2}, \\
\mathrm{BDD}\end{array}$ & $100 \%$ & $10-70$ & [87] \\
\hline $\begin{array}{l}\text { Synthetic dye } \\
\text { wastewater }\end{array}$ & Colour & BDD & $100 \%$ & $4-50$ & {$[88]$} \\
\hline $\begin{array}{l}\text { Synthetic dye } \\
\text { wastewater }\end{array}$ & Colour & $\begin{array}{l}\mathrm{Ti} / \mathrm{SnO}_{2-} \\
\mathrm{Sb} / \mathrm{PbO}_{2}\end{array}$ & $100 \%$ & $5-40$ & [89] \\
\hline $\begin{array}{l}\text { Olive mill } \\
\text { wastewater }\end{array}$ & COD, colour & $\mathrm{Ti} / \mathrm{TiRuO}_{2}$ & $100 \%$ & 60 & {$[100]$} \\
\hline $\begin{array}{l}\text { Olive mill } \\
\text { wastewater }\end{array}$ & Colour, phenols & $\mathrm{Ti} / \mathrm{IrO}_{2}$ & $100 \%$ & 50 & [101] \\
\hline $\begin{array}{l}\text { Synthetic } \\
\text { wastewater }\end{array}$ & Paracetamol & BDD & $\begin{array}{l}>98 \% \text { of TOC } \\
\text { decay }\end{array}$ & $33-150$ & {$[102]$} \\
\hline $\begin{array}{l}\text { Tannery } \\
\text { wastewater }\end{array}$ & $\begin{array}{l}\text { COD, ammonia, } \\
\text { Cr, sulphides }\end{array}$ & $\begin{array}{l}\mathrm{Ti} / \mathrm{Pt}-\mathrm{Ir}, \\
\mathrm{Ti} / \mathrm{PbO}_{2}, \\
\mathrm{Ti} / \mathrm{PdO}- \\
\mathrm{Co}_{3} \mathrm{O}_{4}, \\
\mathrm{Ti} / \mathrm{RhO}_{x}-\mathrm{TiO}_{2}\end{array}$ & $\begin{array}{l}\text { Satisfactory } \\
\text { with all anodes }\end{array}$ & 20 and 40 & [103] \\
\hline $\begin{array}{l}\text { Pulp } \\
\text { bleaching } \\
\text { effluent }\end{array}$ & Pentachlorophenol & Graphite & $100 \%$ & 6 & {$[75]$} \\
\hline $\begin{array}{l}\text { Paper mill } \\
\text { effluent }\end{array}$ & $\begin{array}{l}\text { Organic material: } \\
\text { COD }\end{array}$ & Lead & $>96 \%$ & $2.2-11$ & [67] \\
\hline $\begin{array}{l}\text { Dye } \\
\text { wastewater }\end{array}$ & $\begin{array}{l}\text { Anthraquinone } \\
\text { dye }\end{array}$ & BDD & $100 \%$ & 30 & {$[83]$} \\
\hline
\end{tabular}


Table contd.

\begin{tabular}{|c|c|c|c|c|c|}
\hline Matrix & Pollutant & Electrodes & $\begin{array}{l}\text { Removal } \\
\text { efficiency }\end{array}$ & $\begin{array}{l}\text { Current } \\
\text { densities used } \\
\left(\mathrm{mA} / \mathrm{cm}^{2}\right)\end{array}$ & Ref. \\
\hline $\begin{array}{l}\text { Synthetic } \\
\text { wastewater }\end{array}$ & Phenol & $\begin{array}{l}\mathrm{Ti} / \mathrm{SnO}_{2}-\mathrm{Sb}, \\
\mathrm{Ti} / \mathrm{RuO}_{2}, \mathrm{Pt}\end{array}$ & $100 \%$ & 20 & [104] \\
\hline $\begin{array}{l}\text { Coking } \\
\text { wastewater }\end{array}$ & $\begin{array}{l}\text { Organic pollutants } \\
\text { (TOC) }\end{array}$ & BDD & almost $100 \%$ & $20-60$ & [105] \\
\hline $\begin{array}{l}\text { Synthetic } \\
\text { wastewater }\end{array}$ & $\begin{array}{l}\text { 2,4- } \\
\text { dichlorophenol }\end{array}$ & $\begin{array}{l}\text { Ti-based oxide } \\
\text { electrode }\end{array}$ & almost $100 \%$ & $\begin{array}{l}-1.5 \text { to } 1.5 \mathrm{~V} \\
\text { (anodic } \\
\text { potential) }\end{array}$ & [106] \\
\hline $\begin{array}{l}\text { Domestic } \\
\text { wastewater }\end{array}$ & Sulphide & $\begin{array}{l}\mathrm{Ta} / \mathrm{Ir}, \mathrm{Ru} / \mathrm{Ir} \\
\mathrm{Pt} / \mathrm{Ir}, \mathrm{SnO}_{2} \\
\mathrm{PbO}_{2}\end{array}$ & $77-85 \%$ & 10 & [107] \\
\hline $\begin{array}{l}\text { Synthetic } \\
\text { wastewater }\end{array}$ & Ketoprofen & $\mathrm{BDD}$ and $\mathrm{Pt}$ & $100 \%$ & $\begin{array}{l}4.4,8.9 \text { and } \\
13.3\end{array}$ & [108] \\
\hline $\begin{array}{l}\text { Synthetic } \\
\text { wastewater }\end{array}$ & 1,4-dioxane & BDD & $>95 \%$ & 5,15 and 25 & [109] \\
\hline $\begin{array}{l}\text { Landfill } \\
\text { leachate }\end{array}$ & Ammonium & BDD & $100 \%$ & $15-90$ & [110] \\
\hline $\begin{array}{l}\text { Synthetic } \\
\text { wastewater }\end{array}$ & Surfactants (TOC) & BDD & $82 \%$ & $4-20$ & [111] \\
\hline $\begin{array}{l}\text { Synthetic } \\
\text { wastewater }\end{array}$ & $\begin{array}{l}\text { 4,6-dinitro- } O \text { - } \\
\text { cresol }\end{array}$ & BDD & $100 \%$ & $33-150$ & [112] \\
\hline $\begin{array}{l}\text { Synthetic } \\
\text { wastewater }\end{array}$ & Triclosan & BDD & $>99 \%$ & $6-15$ & [113] \\
\hline $\begin{array}{l}\text { Synthetic } \\
\text { wastewater }\end{array}$ & Progesterone & BDD & $\begin{array}{l}\text { Almost } \\
\text { complete }\end{array}$ & $15-100$ & [114] \\
\hline $\begin{array}{l}\text { Synthetic } \\
\text { wastewater }\end{array}$ & Sulfamethoxazole & BDD & $\begin{array}{l}\text { to below } 0.1 \\
\mu \mathrm{g} / \mathrm{L}\end{array}$ & $15-100$ & [115] \\
\hline
\end{tabular}


Table contd.

\begin{tabular}{|c|c|c|c|c|c|}
\hline Matrix & Pollutant & Electrodes & $\begin{array}{l}\text { Removal } \\
\text { efficiency }\end{array}$ & $\begin{array}{l}\text { Current } \\
\text { densities used } \\
\left(\mathbf{m A} / \mathbf{c m}^{2}\right)\end{array}$ & Ref. \\
\hline $\begin{array}{l}\text { Synthetic } \\
\text { wastewater }\end{array}$ & Chlorpyrifos & BDD & $100 \%$ & 15 and 30 & [116] \\
\hline $\begin{array}{l}\text { Citric acid } \\
\text { wastewater }\end{array}$ & Organic pollutants & $\mathrm{Ti} / \mathrm{RuO}_{2}-\mathrm{IrO}_{2}$ & Almost $100 \%$ & $\begin{array}{l}9 \mathrm{~V} \text { (cell } \\
\text { potential) }\end{array}$ & [117] \\
\hline $\begin{array}{l}\text { Synthetic } \\
\text { wastewater }\end{array}$ & Chloroxylenol & $\mathrm{Pt}, \mathrm{BDD}$ & $\begin{array}{l}100 \% \text { (with } \\
\text { BDD) }\end{array}$ & $33,100,150$ & [118] \\
\hline $\begin{array}{l}\text { Synthetic } \\
\text { wastewater }\end{array}$ & Diclofenac & $\mathrm{Pt}, \mathrm{BDD}$ & $100 \%$ & 150 & [119] \\
\hline $\begin{array}{l}\text { Synthetic } \\
\text { wastewater }\end{array}$ & Atrazine & BDD & up to $94 \%$ & 100 & [120] \\
\hline
\end{tabular}

EO treatment achieved $100 \%$ removal of colour from olive mill wastewaters by DSA electrodes $[100,101]$. In both cases indirect oxidation by active chlorine took place. Also, bulk electrolysis of wastewater showed that degradation proceeded through partial oxidation reactions to intermediates that are eventually mineralized to carbon dioxide and water [101].

The effect of experimental parameters on oxidation results has been investigated in several papers. Commonly increasing the $\mathrm{pH}$ improves pollutant degradation efficiency [106,108,111]. Contrarily, the opposite has also been observed [112]. Higher current density [105,108,111,112], temperature $[105,109,112]$ and initial pollutant concentration also increase the removal rates $[111,112]$.

Based on the results in Table 4, it can be concluded that BDD electrodes are highly efficient for the removal of different organic pollutants. Degradation current efficiencies can vary significantly, 
however, and it is important to achieve the required removal efficiency by adjusting the applied current density together with the removal time and energy consumption of the process [109].

One novel approach is to use solar photo-assisted EO treatment for organic pollutant degradation $[121,122]$. It allows more rapid mineralization of carboxylic acids [121] and photovoltaic solar EO is a self-sustaining wastewater treatment process [122]. The main benefits can be summarized as follows: there is no need for energy storage systems and sun energy can be directly supplied to the treatment process [122].

Comparison of different AOP's (such as EO, ozonation and Fenton oxidation) shows that all technologies can reduce the organic content of wastewaters but with different performances $[123,124]$. EO was the most efficient in mineralization of enrofloxacin but not as effective as ozonation in COD removal [123]. Removal of organic material also seems to depend greatly on the addition of an electrolyte salt in EO treatment [124]. The differences in purification efficiencies can be explained mainly in terms of the contribution of hydroxyl radicals and other oxidation mechanisms involved in each technology.

\subsubsection{Disinfection of wastewater and drinking water}

Electrochemical oxidation has also been used in disinfection of drinking water and various wastewaters. Jeong et al. [125] applied EO to disinfect Escherichia coli in drinking water. They found that the main mechanism was inactivation of bacteria by hydroxyl radicals produced by water discharge, also involving direct oxidation at the electrode surface. ROS can also cause effective inactivation [61,126-128]. It was observed that different electrodes have different abilities to produce radicals, e.g. BDD electrodes prefer to form hydroxyl radicals and DSA electrodes activate chlorine, depending on the electrolyte solution used [127]. Also, inactivation of E. coli at BDD and Pt electrodes was mainly achieved by the reaction of hydroxyl radical and the direct electron transfer 
reaction, respectively. Ma et al. [128] noticed that a hemin/graphite electrode was preferable to produce ROS compounds, such as $\mathrm{H}_{2} \mathrm{O}_{2}$ and ${ }^{*} \mathrm{OH}$, at the cathode surface when applying low potentials without any addition of chloride. A sterilizing rate as high as $99.9 \%$ could be obtained after 60 minutes of inactivation. Fang et al. [129] and Drees et al. [130] also observed effective bacteriophage MS2 inactivation in drinking water. Yet the inactivation rate for bacteriophage MS2 was much lower than for $E$. coli demonstrating that bacteria are more sensitive to electrochemical inactivation than bacteriophages [130]. Electrochemically generated oxidants were a major cause of inactivation within the electrochemical cells.

EO has also been applied in Legionella bacteria disinfection of germinated brown rice circulating waters and cooling tower waters [131]. Disinfection was attributed to the synergistic effects of the oxide anode, the electric field and the radicals formed during the treatment. This observation strongly suggests that electrochemical oxidation could be applicable to the disinfection of waters from other sources. The technique has shown its potential also in the treatment of municipal wastewaters [132] and for disinfection in seawater desalination systems where biofouling of the desalination plant membranes can be prevented without using chlorination [133]. Total removal of coliform bacteria was achieved with very different raw wastewaters and the main disinfectants produced depended on the applied current density, the concentration of chlorides and the concentration of non-oxidized nitrogen in the electrolyte [132].

Though EO has shown promising results in wastewater purification from organic pollutants and disinfection of drinking water, it has its drawbacks. For example some disinfection by-products, such as perchlorates or bromates, can be produced during the treatment. Oh et al. [134] observed that this phenomenon occurred during the desalination treatment of seawater and bromate concentrations were some orders of magnitude higher than the USEPA regulation. It was strongly indicated that the application of electrochemical treatment to seawater desalination cannot be recommended without the 
control of bromate by-product formation. It is also possible to find nitrite, ammonia and monochloramine residues in drinking water disinfection depending on the treatment conditions and original water quality parameters [135].

EO has been applied also to ballast water treatment in the disinfection of Artemia salina [136] and for algae removal using Chlorella vulgaris as a model organism [137]. A current density of $135 \mathrm{~mA} / \mathrm{cm}^{2}$ and a treatment time of around 1 minute could achieve $100 \%$ mortality of $A$. salina, the main oxidant being chlorine together with direct oxidation at the anode surface [136]. Total inactivation of $C$. vulgaris was achieved by EO when $100 \mathrm{mg} / \mathrm{L}$ of chloride was present in the solution so the main mechanism killing the algae was long life oxidants electrogenerated at the anode surface [137].

Some studies of electrochemical disinfection of different microbes are presented in Table 5 .

Table 5. EO treatment in disinfection of different waters

\begin{tabular}{|c|c|c|c|c|c|}
\hline Matrix & Microbe & Anode & $\begin{array}{l}\text { Removal } \\
\text { efficiency }\end{array}$ & $\begin{array}{l}\text { Current } \\
\text { densities used } \\
\left(\mathbf{m A} / \mathbf{c m}^{2}\right)\end{array}$ & Ref. \\
\hline $\begin{array}{l}\text { Synthetic } \\
\text { water }\end{array}$ & Escherichia coli & $\mathrm{Pt}$ & $90 \%$ & $0-100$ & {$[125]$} \\
\hline Tap water & Escherichia coli & BDD & 5 log reduction & 24 and 216 & {$[126]$} \\
\hline $\begin{array}{l}\text { Synthetic } \\
\text { water }\end{array}$ & Escherichia coli & $\begin{array}{l}\mathrm{BDD}, \\
\mathrm{Ti} / \mathrm{RuO}_{2}, \\
\mathrm{Ti} / \mathrm{IrO}_{2}, \mathrm{Ti} / \mathrm{Pt}- \\
\mathrm{IrO}_{2}, \mathrm{Pt}\end{array}$ & $\begin{array}{l}2.4 \log \\
\text { reduction } \\
(\mathrm{BDD})\end{array}$ & $17-167$ & {$[127]$} \\
\hline $\begin{array}{l}\text { Synthetic } \\
\text { water }\end{array}$ & Escherichia coli & Graphite felt & almost $100 \%$ & $\begin{array}{l}-0.6 \mathrm{~V} \text { vs. SCE } \\
\text { (anodic } \\
\text { potential) }\end{array}$ & {$[128]$} \\
\hline
\end{tabular}


Table contd.

\begin{tabular}{|c|c|c|c|c|c|}
\hline Matrix & Microbe & Anode & $\begin{array}{l}\text { Removal } \\
\text { efficiency }\end{array}$ & $\begin{array}{l}\text { Current } \\
\text { densities used } \\
\left(\mathbf{m A} / \mathbf{c m}^{2}\right)\end{array}$ & Ref. \\
\hline $\begin{array}{l}\text { Synthetic } \\
\text { water }\end{array}$ & $\begin{array}{l}\text { Bacteriophage } \\
\text { MS2 }\end{array}$ & $\begin{array}{l}\text { Ti pellet with } \\
\text { a thin layer of } \\
\mathrm{IrO}_{2}-\mathrm{Sb}_{2} \mathrm{O}_{5}- \\
\mathrm{SnO}_{2}\end{array}$ & 8 log reduction & $0.20 \mathrm{~A}$ & [129] \\
\hline $\begin{array}{l}\text { Synthetic } \\
\text { water }\end{array}$ & $\begin{array}{l}\text { Escherichia coli, } \\
\text { Pseudomonas } \\
\text { aeruginosa, } \\
\text { bacteriophages } \\
\text { MS2 and PRD1 }\end{array}$ & $\begin{array}{l}\text { Pt-tipped } \\
\text { copper wire }\end{array}$ & $\begin{array}{l}\text { even } 4 \text { log } \\
\text { reduction }(P \text {. } \\
\text { aeruginosa })\end{array}$ & $5-350 \mathrm{~mA}$ & {$[130]$} \\
\hline $\begin{array}{l}\text { Germinated } \\
\text { brown rice } \\
\text { circulating } \\
\text { water and } \\
\text { cooling tower } \\
\text { water }\end{array}$ & Legionella & $\mathrm{Ti} / \mathrm{RuO}_{2}$ & $100 \%$ & $\begin{array}{l}1.0 \text { and } 1.5 \mathrm{kV} \\
\text { (cell potential) }\end{array}$ & [131] \\
\hline $\begin{array}{l}\text { Municipal } \\
\text { wastewater }\end{array}$ & Escherichia coli & BDD & $100 \%$ & $1.3-13$ & [132] \\
\hline Sea water & Bacillus sp. & - & $100 \%$ & 110 & [133] \\
\hline $\begin{array}{l}\text { Tertiary } \\
\text { treated } \\
\text { wastewater }\end{array}$ & Escherichia coli & BDD & $100 \%$ & 2.1 & [138] \\
\hline $\begin{array}{l}\text { Saline } \\
\text { secondary } \\
\text { effluent }\end{array}$ & Coliform bacteria & $\mathrm{Ti} / \mathrm{RuO}_{2} / \mathrm{TiO}_{2}$ & $99.9 \%$ & $0-30$ & [139] \\
\hline $\begin{array}{l}\text { Biologically } \\
\text { treated } \\
\text { wastewater }\end{array}$ & Coliform bacteria & BDD & 4 log reduction & $2.5-120$ & [140] \\
\hline $\begin{array}{l}\text { Synthetic } \\
\text { water }\end{array}$ & $\begin{array}{l}\text { Escherichia coli } \\
\mathrm{K}-12\end{array}$ & BDD & $100 \%$ & $5-40$ & [141] \\
\hline
\end{tabular}


Table contd.

\begin{tabular}{llllll}
\hline $\begin{array}{l}\text { Synthetic } \\
\text { water }\end{array}$ & $\begin{array}{l}\text { Escherichia coli } \\
\text { K-12 }\end{array}$ & BDD & Almost 100\% & 20 & [142] \\
\end{tabular}




\section{OBJECTIVES OF THE STUDY}

The overall objective of this study was to investigate the inactivation of biofilm forming bacteria present in a paper mill environment by electro-oxidation (EO). The main goal was to discover electrochemical behaviour and the efficiency of different electrode materials during the treatment. Another focus of the research was the applicability of EO to sulphide and organic material removal in real paper mill wastewaters. The enhancement of treatment together with biocides (such as hydrogen peroxide) was a further research interest.

The specific aims of the study were:

1. Investigating the electrochemical behaviour of some electrode materials in paper mill water and their inactivation efficiency against primary biofilm forming bacteria Deinococcus geothermalis, Meiothermus silvanus and Pseudoxanthomonas taiwanensis and discovering the main inactivation mechanisms. Studying the influence of parameters, such as current density and initial $\mathrm{pH}$ or chloride concentration of paper mill water on the inactivation efficiencies (Papers I and II).

2. Studying the efficiency of the EO treatment in sulphide removal from paper mill wastewaters and inactivation of sulphide forming anaerobic bacteria (Paper III)

3. Studying the electrochemical behaviour of electrodes combined with biocides in paper mill water and discovering the oxidation and radical formation mechanisms. Finding the synergistic effects when combining biocides with polarization treatment (Paper IV).

4. Investigating EO in the degradation of methyl orange dye in synthetic wastewater and studying effect of key operative parameters on degradation efficiency. Discovering the oxidation mechanism (Paper V).

5. Discovering the purification efficiency of EO compared to some other common 
physico-chemical treatment methods used in pulp and paper mill wastewater treatment (Paper VI). 


\section{MATERIALS AND METHODS}

\subsection{Reactors and electrodes}

The electrochemical treatment system used for electro-oxidation of Deinococcus geothermalis bacteria in paper $\mathbf{I}$ is shown in Fig. 3.

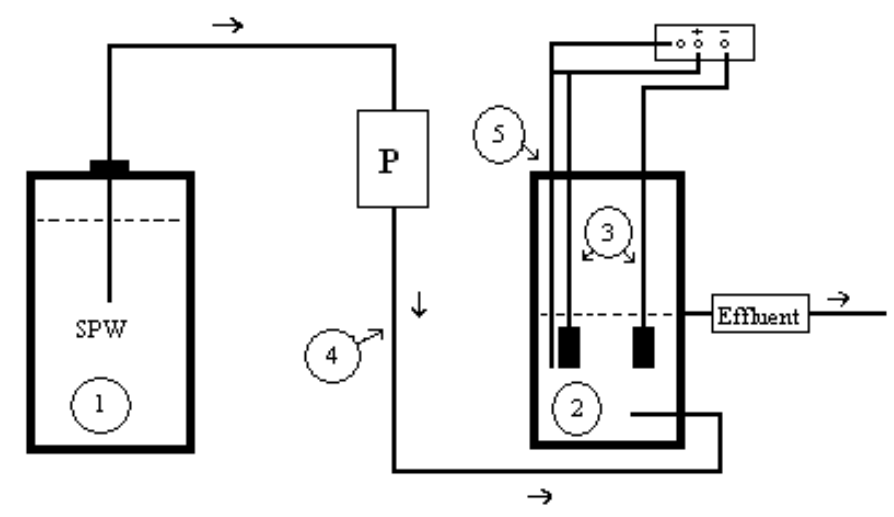

Figure 3. Electrochemical oxidation reactor used in Paper $\mathbf{I}$
1. Sample tank $(\mathrm{V}=5 \mathrm{~L})$
2. Electro-oxidation reaction tank $(\mathrm{V}=75 \mathrm{~mL})$
3. Electrodes $\left(\mathrm{A}=1 \mathrm{~cm}^{2}\right)$
4. Tube (diameter $=8 \mathrm{~mm})$
5. Reference electrode (Saturated calomel electrode, SCE)
P: Tube pump pumping a water sample from the sample tank to the reaction tank

For the experiments in papers II, III, IV and $\mathbf{V}$ a sterile beaker was used as a reaction chamber. Volumes, electrode materials and current densities used for the experiments in this study are presented in Table 6. SCE was selected as the reference electrode. 
Table 6. Experimental parameters

\begin{tabular}{|c|c|c|c|c|c|}
\hline & $\begin{array}{l}\text { Reaction } \\
\text { chamber and } \\
\text { volume }\end{array}$ & Pollutant & $\begin{array}{l}\text { Anode } \\
\text { material }\end{array}$ & $\begin{array}{l}\text { Cathode } \\
\text { material }\end{array}$ & $\begin{array}{l}\text { Current densities } \\
\text { used }\left(\mathrm{mA} / \mathrm{cm}^{2}\right)\end{array}$ \\
\hline Paper I & $75 \mathrm{~mL}$ & $\begin{array}{l}\text { Deinococcus } \\
\text { geothermalis E50051 }\end{array}$ & $\begin{array}{l}\mathrm{PbO}_{2}, \mathrm{MMO} \\
\text { and } \mathrm{BDD}\end{array}$ & Pt wire & $25-75$ \\
\hline Paper II & $250 \mathrm{~mL}$ & $\begin{array}{l}\text { Deinococcus } \\
\text { geothermalis E50051, } \\
\text { Pseudoxanthomonas } \\
\text { taiwanensis JN1109, } \\
\text { Meiothermus silvanus } \\
\text { B-R2A5-50.4 }\end{array}$ & MMO & $\begin{array}{l}\text { Stainless } \\
\text { steel rod }\end{array}$ & $5-65$ \\
\hline Paper III & $500 \mathrm{~mL}$ & $\begin{array}{l}\text { Sulphide, anaerobic } \\
\text { bacteria }\end{array}$ & MMO & $\mathrm{MMO}$ & $14.3-42.9$ \\
\hline Paper IV & $500 \mathrm{~mL}$ & - & $\begin{array}{l}\text { MMO, } \\
\text { stainless } \\
\text { steel } 2343\end{array}$ & MMO & - \\
\hline Paper V & $200 \mathrm{~mL}$ & Methyl orange dye & MMO, BDD & $\begin{array}{l}\text { Stainless } \\
\text { steel plate }\end{array}$ & 30 and 50 \\
\hline
\end{tabular}


Table contd.

\begin{tabular}{llllll}
\hline & $\begin{array}{l}\text { Reaction } \\
\text { chamber and }\end{array}$ & Pollutant & Anode & Cathode & Current densities \\
& volume & material & material & used $\left(\mathbf{m A} / \mathbf{c m}^{2}\right)$ \\
& & & & \\
\hline Paper VI & $3 \mathrm{~L}$ & COD, resin acids & BDD, MMO & BDD, MMO & 4.7 and 9.5 \\
\hline
\end{tabular}

Figure 4 shows the experimental apparatus of the electrochemical system in paper VI. The reactor was equipped with circulation. Two types of electrodes were tested as anodes and cathodes; BDD electrodes and MMO electrodes. The surface area of the BDD anode was $644 \mathrm{~cm}^{2}$ and the current density used was $4.7 \mathrm{~mA} / \mathrm{cm}^{2}$. The surface area of the MMO anode was $315 \mathrm{~cm}^{2}$ and the current density used was $9.5 \mathrm{~mA} / \mathrm{cm}^{2}$. Stream velocity was adjusted to $1 \mathrm{~L} / \mathrm{min}$ and the volume of the water sample was three litres. The recycling time was 60 minutes and the samples were taken at variable time intervals. 


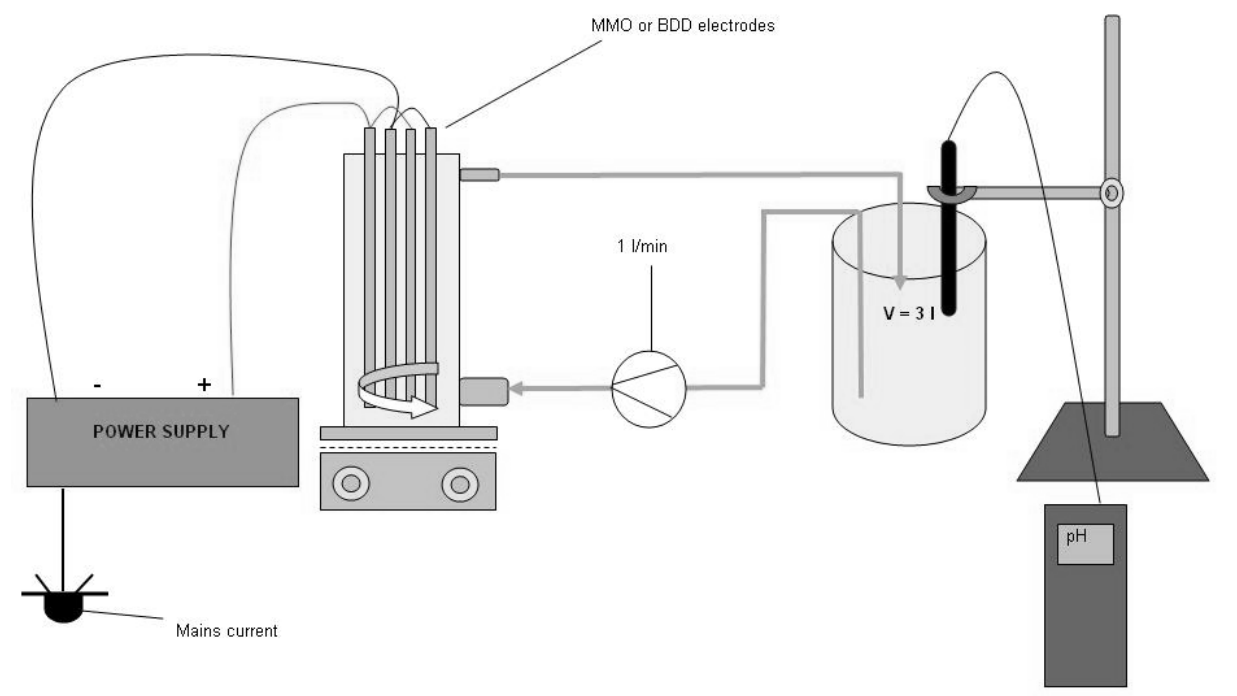

Figure 4. Experimental system for pulp and paper mill effluent treatment in Paper VI

\subsection{Chemicals}

\subsubsection{Wastewaters used for the experiments}

Synthetic paper mill waters were used for the experiments in papers I, II and IV. The composition of the synthetic paper mill water is presented in Table 7 and was developed by Peltola et al. [13]. More detailed compositions are represented in published papers I, II and IV. In paper III real paper mill wastewater was used (Table 8). Methyl orange was used as a pollutant for the experiments in paper V. Finally, in paper VI wastewater samples (Table 9) were obtained from three Finnish pulp and paper mills which produce peroxide bleached mechanical pulp. These mills are hence called mill A, mill B and mill C. Samples were collected after the primary clarifier and biological process. 
Table 7. Composition of synthetic paper mill water [13]

\begin{tabular}{|c|c|}
\hline Substance & $\mathbf{m g} / \mathbf{L}$ \\
\hline $\mathrm{K}_{2} \mathrm{HPO}_{4}\left(3 \mathrm{H}_{2} \mathrm{O}\right)$ & 10 \\
\hline $\mathrm{FeSO}_{4}\left(7 \mathrm{H}_{2} \mathrm{O}\right)$ & 5 \\
\hline $\mathrm{Al}_{2}\left(\mathrm{SO}_{4}\right)_{3}\left(16 \mathrm{H}_{2} \mathrm{O}\right)$ & 200 \\
\hline $\mathrm{CaCl}_{2}\left(2 \mathrm{H}_{2} \mathrm{O}\right)$ & 100 \\
\hline $\mathrm{CaCO}_{3}$ & 700 \\
\hline $\mathrm{Mg}\left(\mathrm{CH}_{3} \mathrm{COO}\right)_{2} 4 \mathrm{H}_{2} \mathrm{O}$ & 61 \\
\hline $\mathrm{MnCl}_{2}$ & 3 \\
\hline $\mathrm{HCOONa}$ & 100 \\
\hline Starch & 100 \\
\hline $\mathrm{C}_{3} \mathrm{H}_{3} \mathrm{NaO}_{3}$ & 100 \\
\hline$\left(\mathrm{NH}_{4}\right)_{2} \mathrm{SO}_{4}$ & 10 \\
\hline $\mathrm{C}_{2} \mathrm{H}_{3} \mathrm{NaO}_{3}$ & 100 \\
\hline AKD-glue & 50 \\
\hline Humic acid & 3 \\
\hline
\end{tabular}


Table 8. Paper mill wastewater characteristics

\section{Parameter}

$\mathrm{pH} \quad 6.5-7.0$

Conductivity $(\mu \mathrm{S} / \mathrm{cm}) \quad 1500-1700$

\begin{tabular}{ll}
\hline Chloride (mg/L) & $60-115$
\end{tabular}

\begin{tabular}{lc}
\hline Sulphate $(\mathrm{mg} / \mathrm{L})$ & 660 \\
\hline $\mathrm{COD}(\mathrm{mg} \mathrm{O} / \mathrm{L})$ & 1500 \\
\hline DOC $(\mathrm{mg} / \mathrm{L})$ & $270-350$ \\
\hline Redox-potential $(\mathrm{mV})$ & $-200--300$ \\
\hline Dissolved oxygen $(\mathrm{mg} / \mathrm{L})$ & $0.5-2$ \\
\hline
\end{tabular}

Sulphide (mg/L) 4-32


Table 9. Wastewater characteristics of Finnish pulp and paper mills

\begin{tabular}{|c|c|c|c|c|c|c|}
\hline \multirow[t]{2}{*}{ Characteristics } & \multicolumn{2}{|c|}{ Mill A } & \multicolumn{2}{|c|}{ Mill B } & \multicolumn{2}{|c|}{ Mill C } \\
\hline & $\begin{array}{c}\text { After } \\
\text { primary } \\
\text { clarifier }\end{array}$ & $\begin{array}{c}\text { After } \\
\text { biological } \\
\text { process }\end{array}$ & $\begin{array}{c}\text { After } \\
\text { primary } \\
\text { clarifier }\end{array}$ & $\begin{array}{c}\text { After } \\
\text { biological } \\
\text { process }\end{array}$ & $\begin{array}{c}\text { After } \\
\text { primary } \\
\text { clarifier }\end{array}$ & $\begin{array}{c}\text { After } \\
\text { biological } \\
\text { process }\end{array}$ \\
\hline $\mathrm{pH}$ & 6.7 & 5.9 & 6.4 & 6.8 & 7.1 & 7.7 \\
\hline $\mathrm{COD}, \mathrm{mgO}_{2} / \mathrm{L}$ & 1550 & 45 & 1029 & 343 & 1440 & 140 \\
\hline $\mathrm{DOC}, \mathrm{mg} / \mathrm{L}$ & 488 & 11 & 390 & 144 & 297 & 55 \\
\hline Colour & 826 & - & 660 & - & 1230 & - \\
\hline Turbidity, FAU & 74 & - & 101 & - & 78 & - \\
\hline Lignin, mg/L & 255 & 16 & 257 & 213 & 296 & 189 \\
\hline $\mathrm{Cl}^{-}, \mathrm{mg} / \mathrm{L}$ & 38 & - & 177 & - & 64 & - \\
\hline Abietic acid, mg/L & 12.4 & nd & 1.1 & nd & 6.0 & nd \\
\hline Oleic acid, mg/L & 7.7 & nd & 14.3 & 5.1 & 5.3 & nd \\
\hline$\beta$-sitosterol, mg/L & 2.4 & nd & 1.7 & nd & 0.1 & nd \\
\hline Conductivity, $\mathrm{mS} / \mathrm{cm}$ & 1.2 & - & 2.0 & - & - & - \\
\hline
\end{tabular}

Remarks:

nd $=$ not detected

- = not analysed 


\subsubsection{Biocides}

The following biocides were tested in combination with polarization in paper IV: hydrogen peroxide p.a. (Merck); peracetic acid, $15 \%$ equilibrium solution (Kemira Chemicals, Oulu, Finland); formic acid, $85 \%$ (Kemira Chemicals, Oulu, Finland); sodium percarbonate, ECOX (Kemira Chemicals, Helsingborg, Sweden); Omacide IPBC 100, 3-Iodo-2-propynyl-n-butylcarbamate (Arch Chemicals, UK); and Fennosan GL10, 50 \% glutaraldehyde; Fennosan M9, $9 \%$ methylene bisthiocyanate (MBT); Fennocide BIT20, $20 \%$ benzisothiazolinone (BIT); and Fennodispo 315, a naphthalene sulphonate containing anionic dispersant, all from Kemira Chemicals, Vaasa, Finland.

\subsection{Bacterial strains}

The bacterial strains used in this study were Deinococcus geothermalis E50051, Pseudoxanthomonas taiwanensis JN1109 and Meiothermus silvanus B-R2A5-50.4. They were selected on the basis of being common primary paper mill bacterial strains [143-145] and were received from the Hambi Collection (Department of Applied Chemistry and Microbiology, Faculty of Agriculture and Forestry, University of Helsinki, Finland) and stored in glycerol freezer stocks $\left(-22{ }^{\circ} \mathrm{C}\right)$. Fresh bacteria were taken for each of the experiments. All bacteria were inoculated into Petri dishes (R2A-agar) and incubated for 3 days $\left(45^{\circ} \mathrm{C}\right)$. After this bacteria were inoculated into five test tubes which had $5 \mathrm{ml}$ of R2 stock solution (composition [per litre]: yeast extract $0.5 \mathrm{~g}$, beef extract $0.25 \mathrm{~g}$, meet peptone $0.25 \mathrm{~g}$, tryptone $0.5 \mathrm{~g}$, starch [soluble] $1.0 \mathrm{~g}, \mathrm{~K}_{2} \mathrm{HPO}_{4} 0.3 \mathrm{~g}, \mathrm{MgSO} 4 * 7 \mathrm{H}_{2} \mathrm{O}$ (dried) $0.05 \mathrm{~g}$, Na-pyruvate $0.3 \mathrm{~g}$ ). Test tubes were incubated for 24 hours $\left(45^{\circ} \mathrm{C}, 70 \mathrm{rpm}\right)$ until cultivated bacteria was ready to use. 


\subsection{Analyses}

\subsubsection{Bacteria}

Amounts of each bacteria species were determined as total aerobic plate counts (APCs) according to the standard method [146] before and after the electro-oxidation treatments (Papers I and II). The bacterium was cultured on PCA agar and incubated at $30^{\circ} \mathrm{C}$ for $72 \pm 3 \mathrm{~h}$. After the incubation period, bacterial colonies were counted and the results calculated as CFU/mL. In Paper III the method was similar but for measuring bacteria an anaerobic atmosphere was created in anaerobic jars (Oxoid Ltd., Hampshire, England) using anaerocults.

\subsubsection{Oxidants}

Measurement of total oxidants (chlorine/hypochlorite, ozone and hydrogen peroxide) was performed according to the standard method [147].

\subsubsection{Cyclic voltammograms}

In paper I and paper IV the electrochemical behaviour of the electrodes was investigated by cyclic voltammetry. In paper I, cyclic voltammograms (CV's) were performed with stirred solutions at scan rates of $25 \mathrm{mV} / \mathrm{min}$ by potentiostat (delivered by Savcor Forest Oy). In paper IV a Princeton ParStat 2273-Potentiostat/Galvanostat was used for CVs. Anodic CVs were run by range $0-1.6 \mathrm{~V}$ vs. SCE $(\mathrm{up}=$ from $0 \mathrm{~V}$ to $1.6 \mathrm{~V}$ and down $=$ from $1.6 \mathrm{~V}$ to $0 \mathrm{~V}$ ) and cathodic curves by range $0--1.9 \mathrm{~V}$ vs. $\mathrm{SCE}(\mathrm{up}=$ from $0 \mathrm{~V}$ to $-1.9 \mathrm{~V}$ and down $=-1.9 \mathrm{~V}$ to $0 \mathrm{~V}$ ) at a scan rate of $25 \mathrm{mV} / \mathrm{s}$.

\subsubsection{Other analyses}

The conductivities of the synthetic and real wastewater samples were measured by conductivity meter (VWR EC300, VWR International) and $\mathrm{pH}$ values and redox potentials by $\mathrm{pH}$ meter using different probes (VWR pH100, VWR International). Dissolved oxygen (DO) measurements were done by DO 
meter (VWR DO200, VWR International). Sulphide, sulphate and chloride concentrations were measured directly without filtration by HACH Lange photometer (DR 2800 VIS Spectrophotometer) using Lange Cuvette tests. DOC values of the samples were measured by TOC-analyzer (Shimadzu, Model TOC-5000A) and COD values by the standard method [148]. DOC samples were filtrated before analysis through $0.45 \mu \mathrm{m}$ membranes.

Wood extractives were analysed adapting a method from Örså and Holmbom [149]. Four millilitres of the sample were measured in a screw capped test tube and the $\mathrm{pH}$ was adjusted to 3.5 with $0.05 \mathrm{M}$ or $0.5 \mathrm{M} \mathrm{H}_{2} \mathrm{SO}_{4}$, depending on initial $\mathrm{pH}$ of the sample. Bromocresol green was used as an indicator. Two millilitres of methyl tert-butyl ether (MTBE), containing $20 \mu \mathrm{l} / \mathrm{ml}$ of heneicosanoic acid and botulin, were also added. The sample was mixed vigorously for two minutes and centrifuged at 4500 rpm for five minutes. A clear organic layer was carefully pipetted off. The extraction was repeated twice with two millilitres of MTBE (without ISTD) and mixed for one minute. The combined MTBE layers were evaporated in a nitrogen stream. The residue was silylated adding $80 \mu \mathrm{L}$ of bis(trimethylsilyl)trifluroacetamide (BSTFA) and $40 \mu \mathrm{l}$ of trimethylchlorosilane (TMCS). The silylation was carried out in an oven at $70{ }^{\circ} \mathrm{C}$ for 20 minutes.

A Hewlett Packard 6890 gas chromatograph (GC) coupled with a 5973 Mass Selective Detector GCMS equipped with a standard capillary column ( $25 \mathrm{~mm}$ x $0.32 \mathrm{~mm}$ I.D. $\times 0.17 \mu \mathrm{m}$ film thickness $)$ containing polydimethylsiloxane was used for measuring resin acids. The initial oven temperature was $120^{\circ} \mathrm{C}$ and the temperature was programmed to $190{ }^{\circ} \mathrm{C}$ at a rate of $10^{\circ} \mathrm{C} / \mathrm{min}$ from which it was raised to $340{ }^{\circ} \mathrm{C}$ at a rate of $3^{\circ} \mathrm{C} / \mathrm{min}$. The final temperature was held for 10 minutes. The inlet temperature was $260{ }^{\circ} \mathrm{C}$. Helium was used as a carrier gas. All the samples were added by splitless injection with a sample volume of $1 \mu$ l. Identification and quantification were performed using heneicosanoic acid as the internal standard for resin acids. 
Dye concentration was determined on a UV-visible spectrophotometer at the maximum visible wavelength of $465 \mathrm{~nm}$ (PerkinElmer Lambda 45). Wastewater mineralization was monitored by the removal of TOC (Shimadzu, Model TOC-5000A). 


\section{RESULTS AND DISCUSSION}

\subsection{Cyclic voltammograms}

To find out the oxygen evolution overpotentials, CV's were recorded for three different electrodes (Paper I). Figure 5 presents CVs recorded in the synthetic paper mill water (SPW). According to the CVs, BDD has the highest oxygen evolution overpotential (2.5 V vs. SCE) of the electrodes, suggesting that instead of molecular oxygen, hydroxyl radicals are formed on the surface of the anode. In addition, $\mathrm{PbO}_{2}$ has a higher oxygen evolution overpotential than the $\mathrm{MMO}$ electrode which belongs to DSA electrodes. This have been reported also by Chen [43].

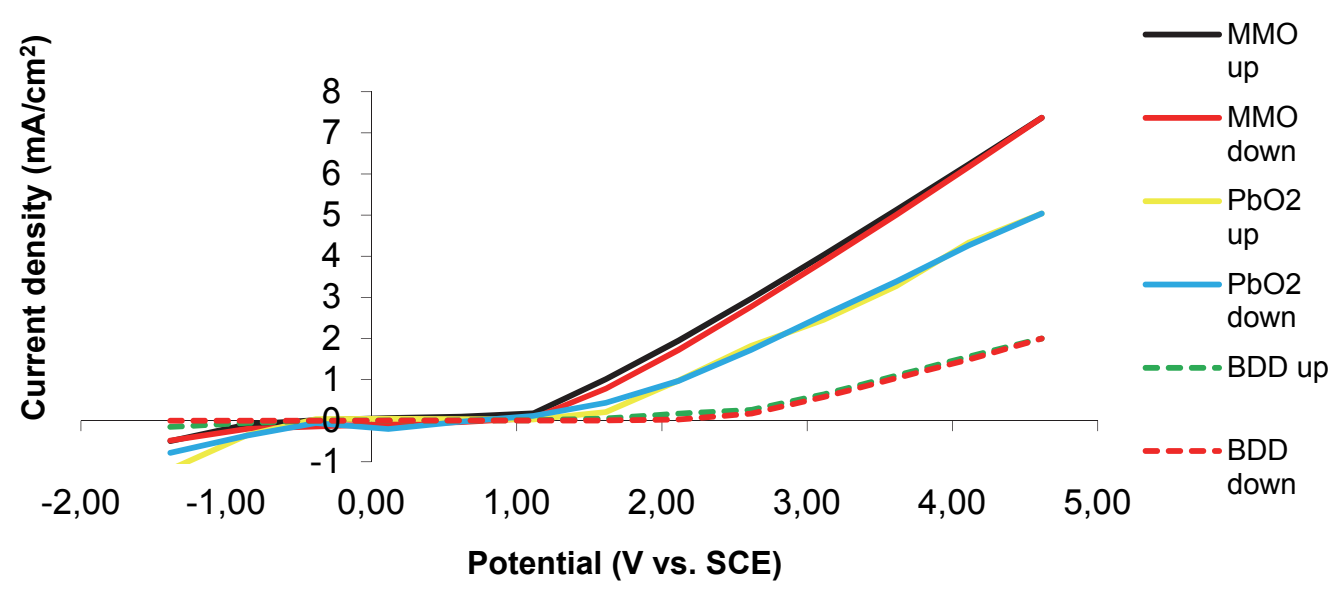

Figure 5. Voltammograms of the anode materials $\mathrm{MMO}, \mathrm{PbO}_{2}$ and $\mathrm{BDD}$ obtained at a scan rate of 25 $\mathrm{mV} / \mathrm{min}$ in SPW at room temperature and $\mathrm{pH}=7$ (Data from paper $\mathbf{I}$ )

In Figure 6 are presented CV's for three electrodes without chloride salts in SPW. BDD seems to have still the highest oxygen evolution overpotential, but the difference between $\mathrm{BDD}$ and $\mathrm{PbO}_{2}$ is not significant. This means that $\mathrm{PbO}_{2}$ can form more hydroxyl radicals on its surface in this SPW than in ordinary SPW containing chloride salts. 


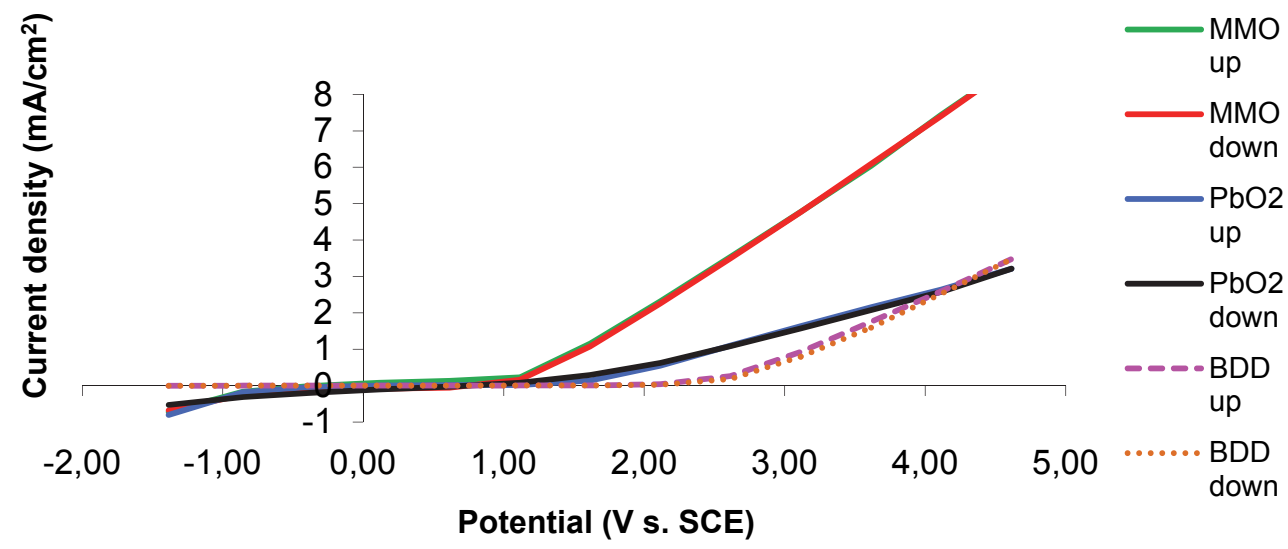

Figure 6. Voltammograms of the anode materials $\mathrm{MMO}, \mathrm{PbO}_{2}$ and $\mathrm{BDD}$ obtained at a scan rate of 25 $\mathrm{mV} / \mathrm{min}$ in SPW (without chloride salts) at room temperature and $\mathrm{pH}=7$ (Data from paper I)

To achieve one of the main objectives of this study, electrochemical properties of electrodes in paper mill water were investigated. The main idea was to observe how well electrochemical treatment can enhance the radical formation reactions in paper mill waters where biocides are already present. If more oxidative radicals can be formed, more efficient biofilm prevention will be also achieved.

Combination of CVs for the MMO and stainless steel SS 2343 electrodes with $\mathrm{H}_{2} \mathrm{O}_{2}$ concentrations of $50 \mathrm{mg} / \mathrm{L}$ are shown in Figures 7-8 (Data from Paper IV). CVs without $\mathrm{H}_{2} \mathrm{O}_{2}$ additions showed good reproducibility through the runs. It can be seen that the added biocide has a clear effect on the surface of the SS 2343 electrode by increasing the currents (between $0.7-1.4 \mathrm{~V}$ vs. SCE) even before the oxygen evolution reactions occur. This was also seen on the cathodic side when hydrogen peroxide caused a current increase during the experiment on the SS 2343 electrode at $-1.0 \mathrm{~V}$ vs. SCE (reduction of $\mathrm{H}_{2} \mathrm{O}_{2}$ ) which was also observed by Patra and Munichandraiah [150]. Thus different radical reactions may occur with hydrogen peroxide. On the MMO electrode, the current also increased between $0.2-1.1 \mathrm{~V}$ vs. SCE. Probably the radicals were formed at the beginning of the run until formation stopped after 1.1 V vs. SCE. A clear current increase was also observed on the 
cathodic side after starting the run on the MMO electrode, indicating radical formation also on this side. On the cathodic side, curves returning back to initial stage show that currents are smaller on both SS 2343 and MMO electrodes. This means that hydrogen peroxide has been degraded during the run to water. More reactive behaviour of SS 2343 electrode must be due to its surface structure. On the cathodic side it can be also seen that hydrogen peroxide has degraded almost completely because it has a similar curve to the SS 2343 electrode without biocide (Fig. 8). It is a clear proof that on the cathodic side, hydrogen peroxide has a capacity to form different radicals in combination with electrical treatment until degraded to water. The proposed radical production mechanism could be as follows (reactions 12-13):

$\mathrm{H}_{2} \mathrm{O}_{2} \rightarrow{ }^{*} \mathrm{OH}+{ }^{*} \mathrm{OH}$

${ }^{*} \mathrm{OH}+\mathrm{H}_{2} \mathrm{O}_{2} \rightarrow \mathrm{HO}_{2}{ }^{*}+\mathrm{H}_{2} \mathrm{O}$

Patra and Munichandraiah [150] suggested that following reactions will occur in direct reduction of $\mathrm{H}_{2} \mathrm{O}_{2}$ in a slightly acidic medium $(\mathrm{pH}=5.8)($ reactions $14-18)$ :

$\mathrm{H}_{2} \mathrm{O}_{2}$ (bulk) $\rightarrow \mathrm{H}_{2} \mathrm{O}_{2}$ (surface)

$\mathrm{H}_{2} \mathrm{O}_{2 \text { (surface) }}+\mathrm{e}^{-} \rightarrow \mathrm{OH}_{\text {ad }}+\mathrm{OH}^{-}$

$\mathrm{OH}^{-}+\mathrm{H}^{+} \rightarrow \mathrm{H}_{2} \mathrm{O}$

$\mathrm{OH}_{\mathrm{ad}}+\mathrm{e}^{-} \rightarrow \mathrm{OH}^{-}$

$\mathrm{OH}_{\mathrm{ad}}+\mathrm{H}^{+}+\mathrm{e}^{-} \rightarrow \mathrm{H}_{2} \mathrm{O}$

Reaction 14 followed by electrontransfer steps (reactions 15 and 17) is expected to result in the CV peak current [150] which we observed at -1.0 V vs. SCE (Fig. 8). 
It is also known that hydrogen peroxide is relatively stable at $\mathrm{pH}<9$ [151] which proofs that $\mathrm{H}_{2} \mathrm{O}_{2}$ was not degraded by itself. Many other biocides were also tested in this study but they did not give any response (oxidation or reduction peaks) for radical formation with electrical treatment (Paper IV). Peltola et al. [13] showed that removal of Deinococcus geothermalis biofilm was enhanced by cathodically weighted pulsed polarization in the presence of oxidizing biocides. ROS compounds were succesfully generated during the experiments for biofilm removal from stainless steel surfaces which supports also results of this study.

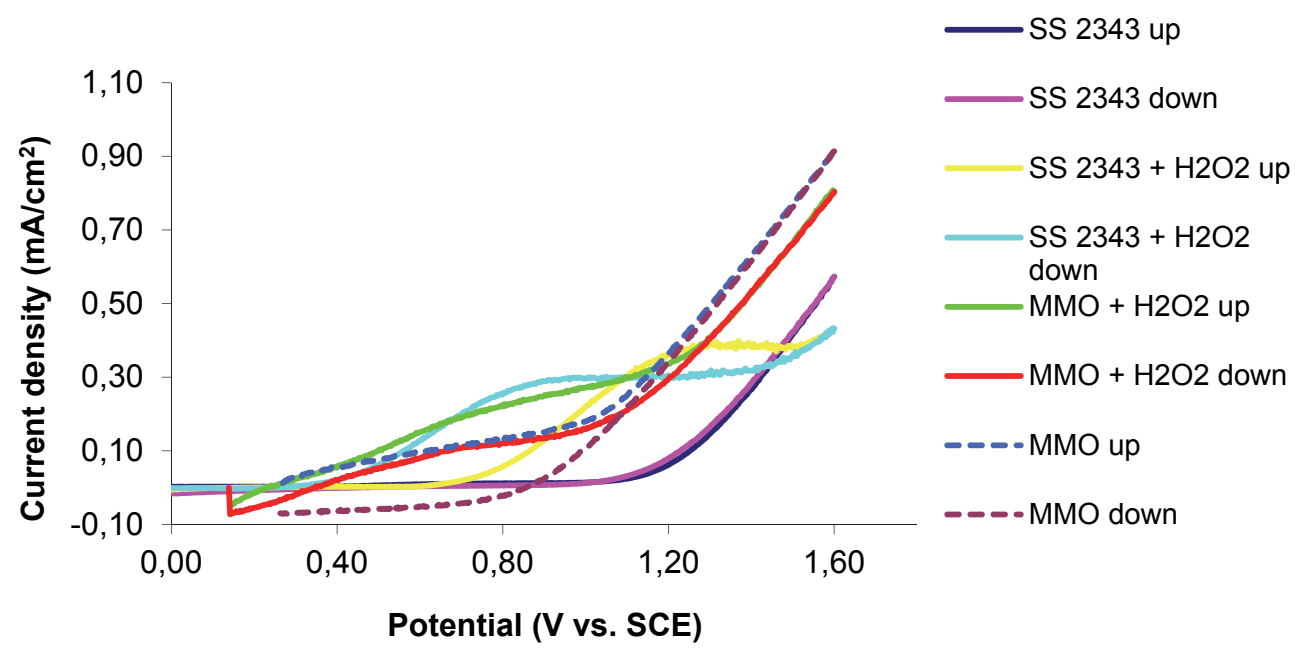

Figure 7. Cyclic voltammograms of hydrogen peroxide in synthetic paper mill water (cPMW) on the anodic side (Data from Paper IV) 


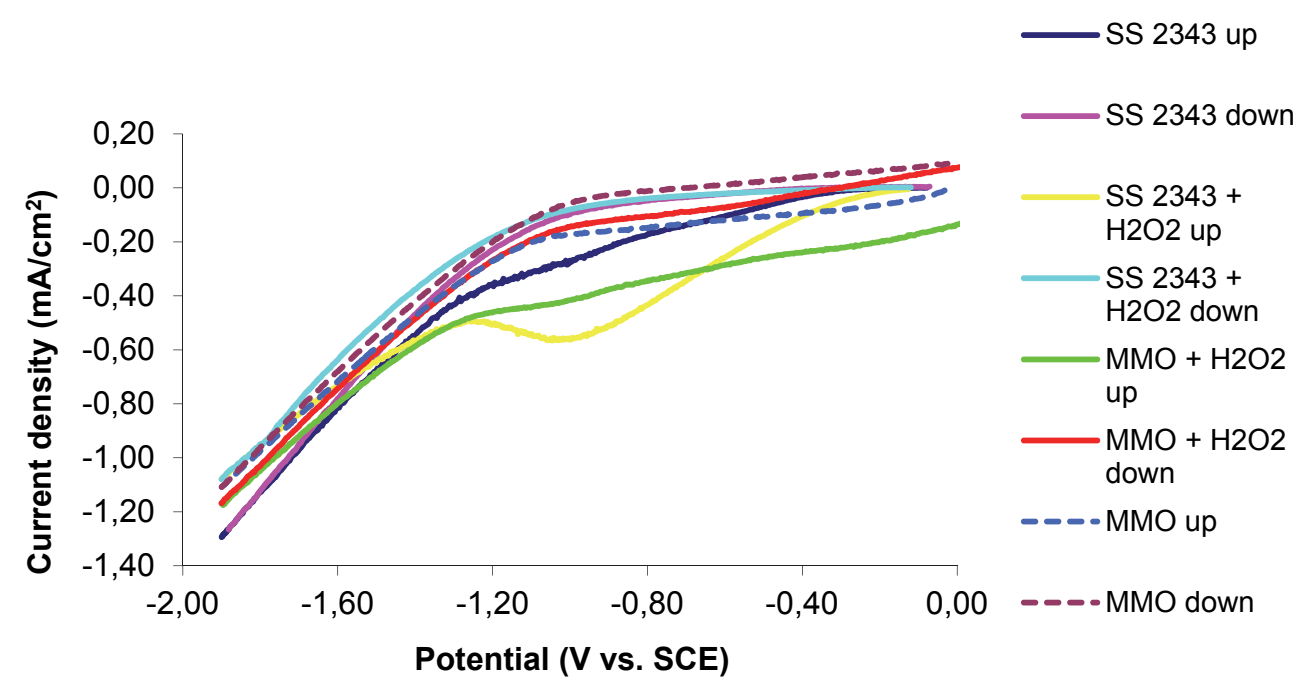

Figure 8. Cyclic voltammograms of hydrogen peroxide in cPMW on the cathodic side (Data from Paper IV)

\subsection{Electrochemical inactivation of bacteria}

\subsubsection{Aerobic bacteria in synthetic paper mill water}

Figure 9 shows the electrochemical inactivation of Deinococcus geothermalis in synthetic paper mill water (SPW) as the current density varied from 5 to $65 \mathrm{~mA} / \mathrm{cm}^{2}$ (Paper II). It can be seen that the effective inactivation $(>2 \log$ ) of bacteria was reached when current density was higher than 25 $\mathrm{mA} / \mathrm{cm}^{2}$ and the time taken was at least three minutes. The inactivation also increased with higher current density which has also been observed in other studies [152,153]. Differences in inactivation in the range of 25 to $65 \mathrm{~mA} / \mathrm{cm}^{2}$ were minor, signifying that above the threshold value $\left(25 \mathrm{~mA} / \mathrm{cm}^{2}\right)$ most of the electric energy used in the experiments was spent to form oxygen. In addition, it can be seen from Figure 10 that different oxidants were formed during the EO. With higher current density it is possible to form more oxidants. The amounts of oxidants produced are in accordance with the 
inactivation rate. In three minutes it was possible to reach a sufficient inactivation level, which means that the concentration of oxidants needed is about $3 \mathrm{mg} / \mathrm{L}$. The amount of oxidant was smaller at a current density of $65 \mathrm{~mA} / \mathrm{cm}^{2}$ than at $50 \mathrm{~mA} / \mathrm{cm}^{2}$. This can be explained by the higher oxygen evolution reaction and hydroxyl radical production at this current density.

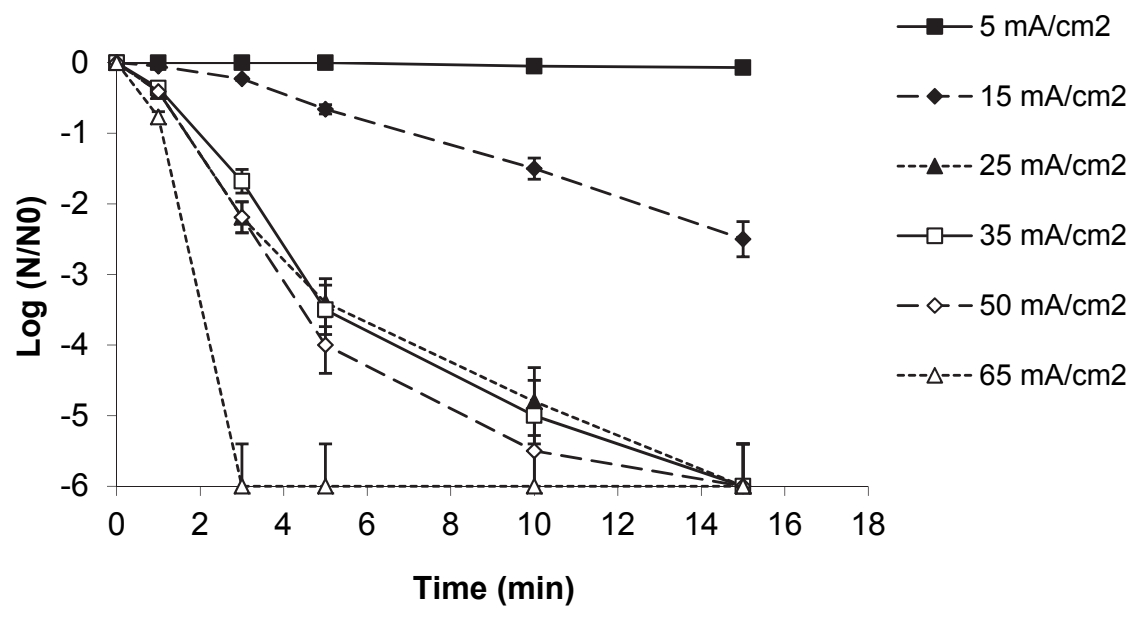

Figure 9. Inactivation of Deinococcus geothermalis in SPW using an MMO electrode and different current densities during galvanostatic electrolysis $(\mathrm{pH}=7)$ (Data from Paper II) 


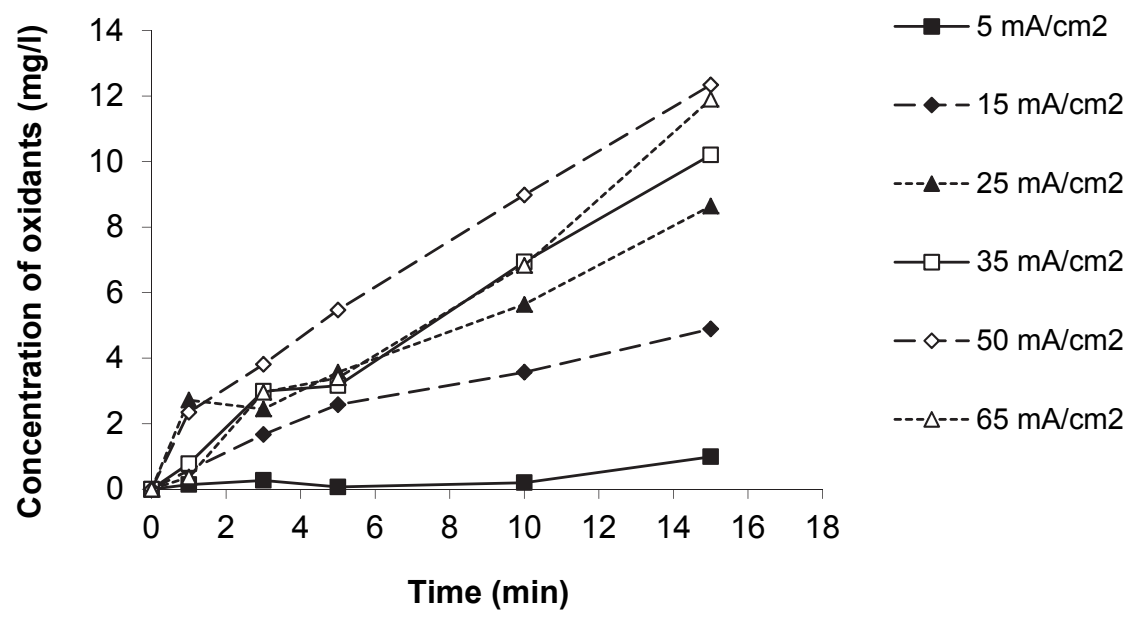

Figure 10. Amounts of oxidants electrochemically generated on an MMO electrode during galvanostatic electrolysis using different current densities at $\mathrm{pH}=7$ (Data from Paper II)

Figure 11 indicates that the $\mathrm{pH}$ of SPW did not have a significant influence on the inactivation efficiency of Deinococcus geothermalis. Almost equal amounts of total oxidants were formed during the experiments (Figure 12). However, less oxidants were produced at lower pHs. Similar inactivation efficiency can be explained by higher oxidation potential of hypochlorous acid formed (reaction 6) at acidic $\mathrm{pH}$. Hypochlorous acid has higher oxidation potential than hypochlorite present at neutral or alkaline $\mathrm{pH}$ (reaction 7) [55]. It was also observed that generation of chlorine is more or less same under the fixed current density [54]. However, in this study also other oxidants than chlorine/hypochlorite could be formed by higher $\mathrm{pH}$. 


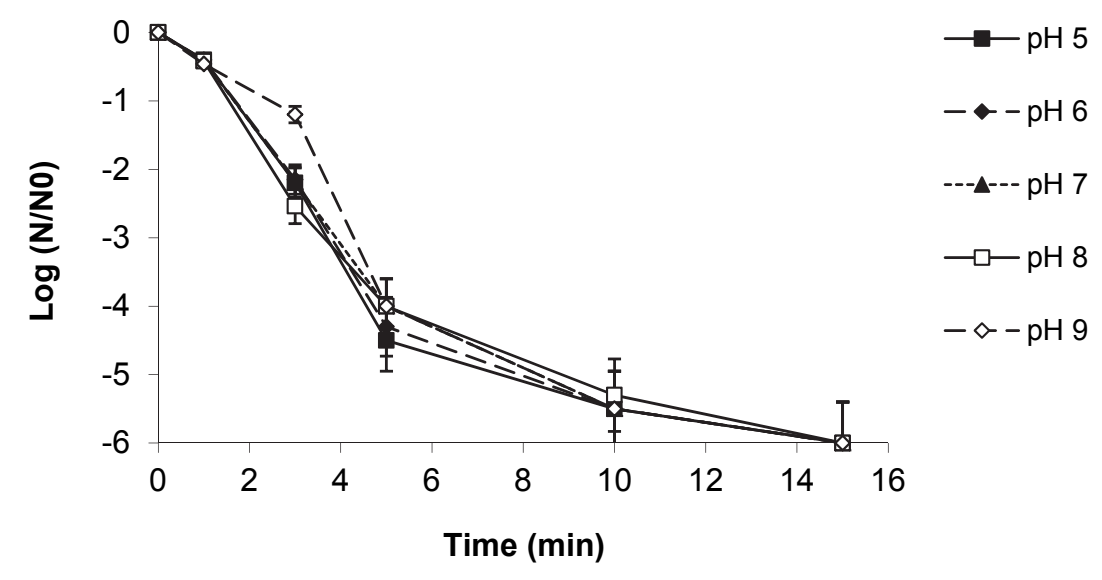

Figure 11. Inactivation of Deinococcus geothermalis in SPW using an MMO electrode at different $\mathrm{pH}$ values during galvanostatic electrolysis (current density $50 \mathrm{~mA} / \mathrm{cm}^{2}$ ) (Data from Paper II)

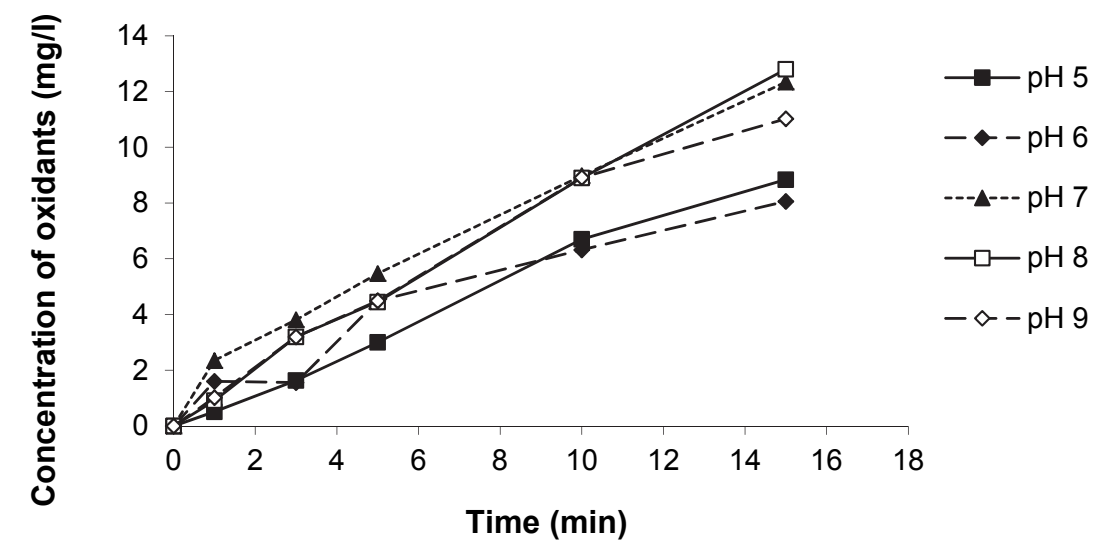

Figure 12. Amounts of electrochemically generated oxidants on MMO electrode during the galvanostatic electrolysis using different $\mathrm{pH}$ values (current density $50 \mathrm{~mA} / \mathrm{cm}^{2}$ ). (Data from Paper II) 
The effect of different chloride concentrations on inactivation efficiency is shown in Figure 13. It is evident that electrochemically generated chlorine/hypochlorite has a significant influence on the inactivation of Deinococcus geothermalis (indirect oxidation). This can also be seen from Figure 14. A $6 \log$ inactivation could be reached in five minutes when the chloride concentration was $130 \mathrm{mg} / \mathrm{l}$ in SPW. However, most likely anodic oxidation by direct electron transfer reaction occurred simultaneously, as well as oxidation by ROS generated from water discharge [125]. It has been also shown that oxidation may occur by peroxodisulfates generated from sulphate ions [141] in SPW but they were not measured in this study. Chemical composition of SPW is very heterogeneous mixture including many different anions which can be oxidized to more reactive form to inactivate bacteria.

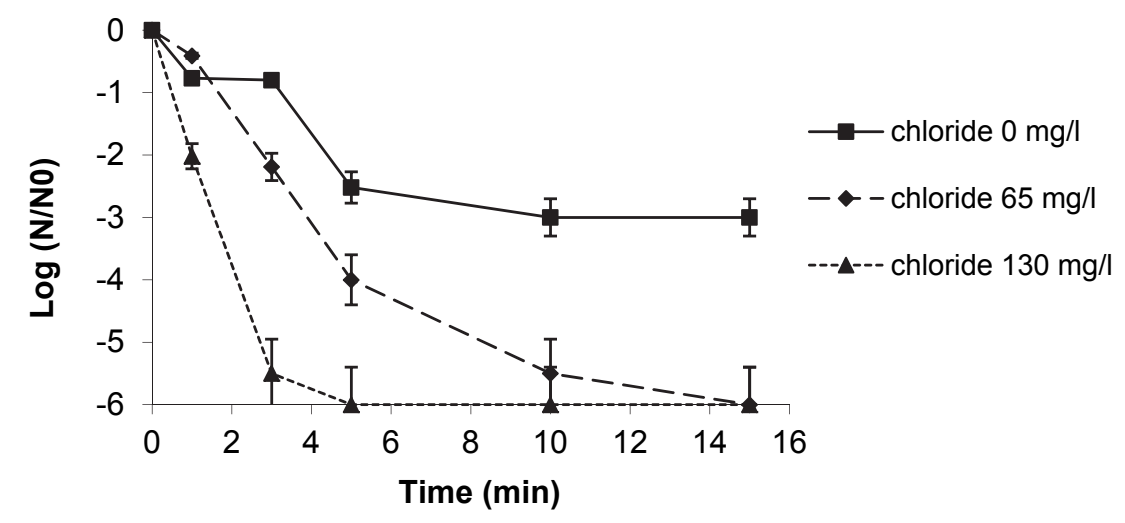

Figure 13. Inactivation of Deinococcus geothermalis using an MMO electrode and different initial chloride concentrations during galvanostatic electrolysis $\left(\mathrm{pH}=7\right.$, current density $\left.50 \mathrm{~mA} / \mathrm{cm}^{2}\right)($ Data from Paper II) 


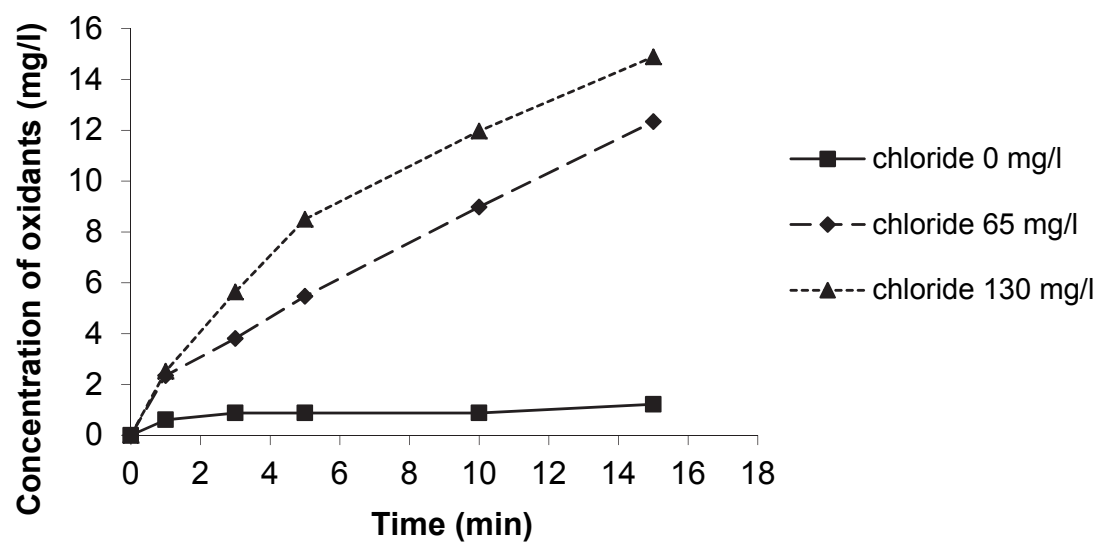

Figure 14. Electrochemically generated oxidants on an MMO electrode during galvanostatic electrolysis using different initial chloride concentrations ( $\mathrm{pH}=7$, current density $50 \mathrm{~mA} / \mathrm{cm}^{2}$ ) (Data from Paper II)

Because it was obvious that chlorine/hypochlorite played a significant role in inactivation, the effect of residual chlorine on Deinococcus geothermalis was investigated. Electrical treatment was switched on for one minute and then switched off. A bacteria sample was taken immediately after switching on and then every minute. Figure 15 shows that with a chloride concentration of $130 \mathrm{mg} / \mathrm{L}$ it was possible to achieve a reasonable inactivation level in five minutes. Figure 15 shows also inactivation was faster when the initial chloride concentration in SPW was higher.

Deinococcus geothermalis has been showed to be an efficient primary biofilm former in paper machine water $[12,16,17]$ and it forms thick biofilms on which secondary biofilm bacteria can further attach [16]. It is known to be highly resistant towards radiation and desiccation so results in our study show that EO treatment can produce effective oxidants to inactivate it. In addition, when Deinococcus 
will be inactivated, it also decreases capability of other potential biofilm formers to attach pipe lines because they cannot adhere on the surfaces without Deinococcus.

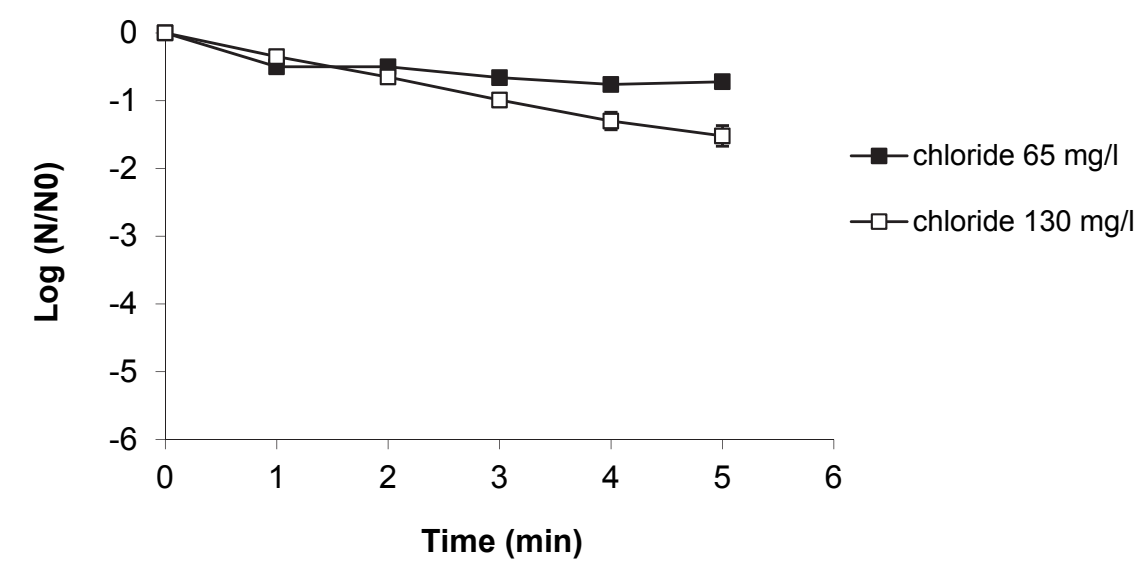

Figure 15. Inactivation of Deinococcus geothermalis using an MMO electrode and different initial chloride concentrations during galvanostatic electrolysis, effect of residual chlorine/hypochlorite ( $\mathrm{pH}=7$, current density $50 \mathrm{~mA} / \mathrm{cm}^{2}$ ) (Data from Paper II)

Three different paper mill bacteria species (Deinococcus geothermalis, Pseudoxanthomonas taiwanensis and Meiothermus silvanus) were compared to discover possible differences in inactivation efficiency. These species have been recognized as pertinent, primary biofilm formers in the wet-end of paper machines and they can cause colourful spots to final product [154]. Experiments were conducted as before (each species was treated separately) and responses to all oxidants (SPW) and oxidants without chlorine/hypochlorite (SPW without chloride salts) were measured. The residual effect of chlorine/hypochlorite on the inactivation efficiency of these three bacteria species was also investigated. 
Figure 16 shows how electrochemical inactivation affected these three bacteria species. The inactivation order was Meiothermus silvanus $>$ Pseudoxanthomonas taiwanensis $>$ Deinococcus geothermalis. Meiothermus silvanus could be inactivated quite effectively (1.5 log) in one minute. The resistance of other bacteria to oxidants was somewhat higher.

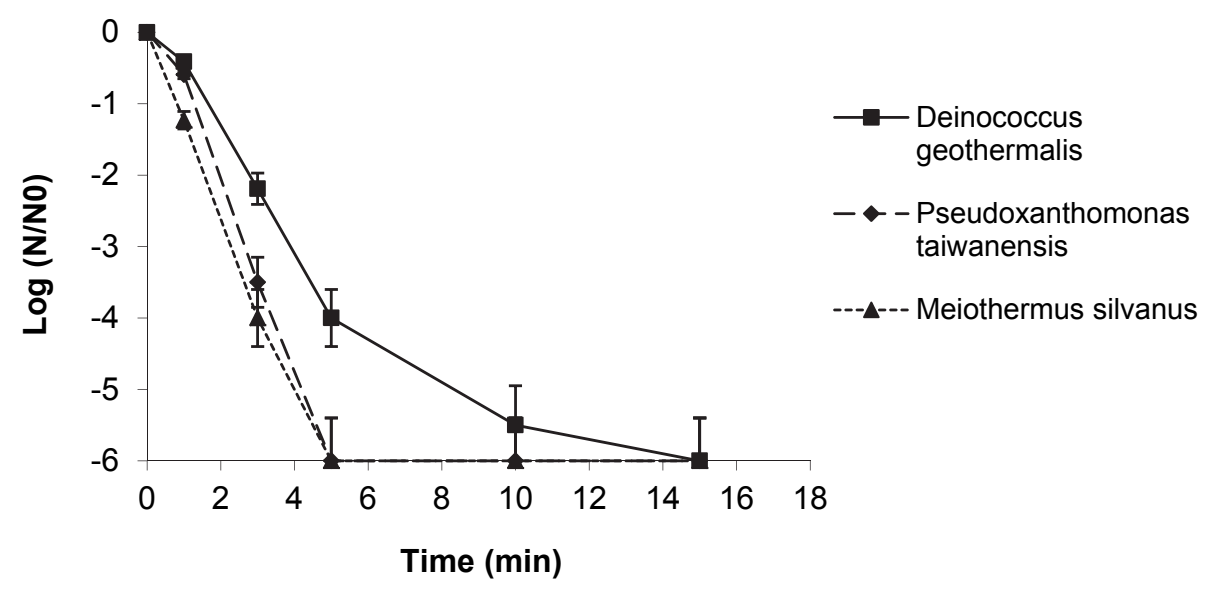

Figure 16. Inactivation of Deinococcus geothermalis, Pseudoxanthomonas taiwanensis and Meiothermus silvanus using an MMO electrode during galvanostatic electrolysis (chloride concentration $65 \mathrm{mg} / \mathrm{L}, \mathrm{pH}=7$, current density $50 \mathrm{~mA} / \mathrm{cm}^{2}$ ) (Data from Paper II)

The same experiments were conducted without chloride salts in SPW (chloride concentration $=0$ $\mathrm{mg} / \mathrm{L}$ ) to compare their influence. Figure 17 indicates that the inactivation order was different to that with chlorine/hypochlorite. Thus bacteria have different abilities to withstand different oxidants. It was also observed that Deinococcus geothermalis was more sensitive to other oxidants than chlorine/hypochlorite. On the other hand, Pseudoxanthomonas taiwanensis was more resistant to these oxidants than to chlorine/hypochlorite. Also Meiothermus silvanus was inactivated with a 
slower response. Li et al. [142] observed that oxidants with high oxidation-reduction potential, such as hydroxyl radical, will damage cell structure more due to strong oxidation ability. For weaker oxidants, such as chlorine, reactions with the cell wall are quite limited and then there is little cell surface deformation. Oxidation with the enzymes in the cell plasma might be the lethal reason. As a conclusion, sensitivity of different bacteria species to different oxidants varies a lot.

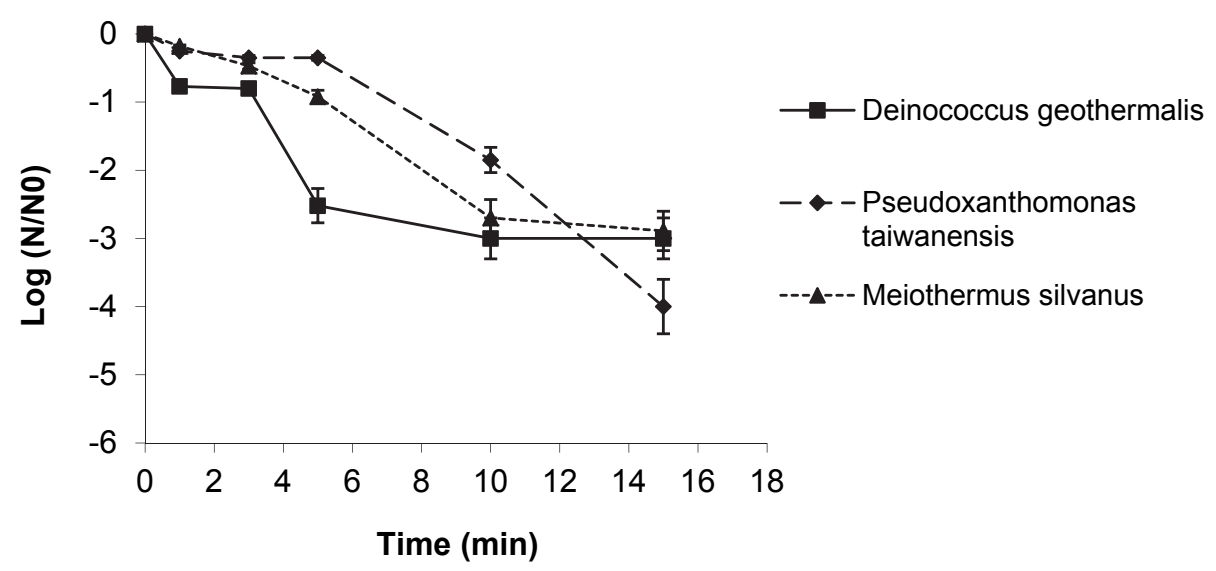

Figure 17. Inactivation of Deinococcus geothermalis, Pseudoxanthomonas taiwanensis and Meiothermus silvanus using an MMO electrode during galvanostatic electrolysis without chloride salts (chloride concentration $0 \mathrm{mg} / 1, \mathrm{pH}=7$, current density $50 \mathrm{~mA} / \mathrm{cm}^{2}$ ) (Data from Paper II)

Figure 18 shows the influence of residual chlorine/hypochlorite on the inactivation efficiency of bacteria species. As expected, the inactivation order was the same as in Figure 16. An efficient inactivation result was achieved with Pseudoxanthomonas taiwanensis and Meiothermus silvanus bacteria in three minutes. Deinococcus geothermalis bacteria were more persistent against residual chlorine/hypochlorite. Thus the effective oxidation noted during the experiments was mainly due to indirect electrochemical oxidation through chlorine/hypochlorite produced on the anode. This 
mechanism has also been reported in many other studies [127,129,132,140,155-157]. The main achievement of the current study is to show that residual disinfection efficiency by chlorine/hypochlorite can keep the circulating waters clean enough to avoid biofilm formation on the pipeline surfaces.

We did not measure in this study hydroxyl radicals which have also important role in disinfection $[125,152]$. In general, inactivation mechanisms in EO are very complex and depend on many factors, such as electrolyte composition, bacteria species, electrodes and operating conditions during the treatment. For example, in disinfecting germinated brown rice circulating water and cooling tower water containing Legionella bacteria it was concluded that electrochemical disinfection was due to synergistic effect of the oxide anode, pulsed electric field and the hydroxyl radicals formed during the electrochemical treatment [131]. Li et al. [139] did similar observation in electrochemical disinfection of saline wastewater effluent.

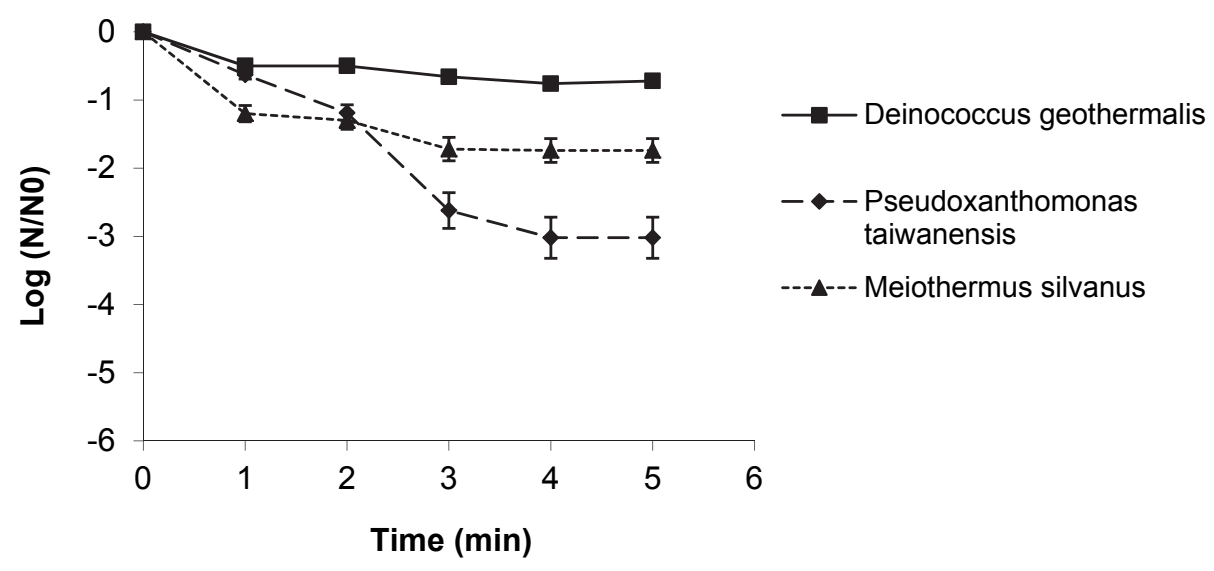

Figure 18. Inactivation of Deinococcus geothermalis, Pseudoxanthomonas taiwanensis and Meiothermus silvanus using an MMO electrode during galvanostatic electrolysis, effect of residual 
chlorine/hypochlorite (chloride concentration $65 \mathrm{mg} / \mathrm{L}, \mathrm{pH}=7$, current density $50 \mathrm{~mA} / \mathrm{cm}^{2}$ ) (Data from Paper II)

\subsubsection{Anaerobic bacteria in paper mill wastewater}

The reduction of sulphate to sulphide by anaerobic bacteria is a serious problem for pulp and paper mills so it was worth of investigating the inactivation efficiency of EO against them (Paper III). Real paper mill wastewater was used for the experiments. Figure 19 shows that inactivation was less effective with chloride concentration (in this case $62 \mathrm{mg} / \mathrm{L}$ ) originally present in the wastewater. Thus, it was justifiable to increase the initial chloride concentration of the wastewater by adding $\mathrm{NaCl}$ to the wastewater. With chloride concentrations of $164 \mathrm{mg} / \mathrm{L}$ and $281 \mathrm{mg} / \mathrm{L}$ it was possible to inactivate anaerobic bacteria effectively in five minutes, so electrochemically produced chlorine species accelerated inactivation. Yet many studies have shown that electrochemical disinfection can be effective against bacteria and viruses without the generation of chlorine species $[125,128,130,141,152,158]$. Jeong et al. [125] observed that in chloride-free phosphate buffer solution E. Coli inactivation occurred in two distinct stages. The first step was direct anodic oxidation at anode's surface and another step oxidation by hydroxyl radicals generated from water discharge. It is also evident that oxygen evolution reaction killed part of the bacteria in this study. Li et al. [141] also showed in their study that oxidants produced in the electrolysis of $\mathrm{SO}_{4}{ }^{2-}$ ( $\operatorname{such}$ as $\mathrm{S}_{2} \mathrm{O}_{8}{ }^{2-}$ ) improved the disinfection process. This phenomenon cannot be ignored in this study either because paper mill wastewater had high concentration of sulphate as well as SPW. Chlorine containing organic and inorganic by-product formation is also expected [134] during electrochemical treatment, but investigation into this was beyond the scope of the present study. However, applying lower current densities could help to avoid formation of hazardous compounds [132]. 


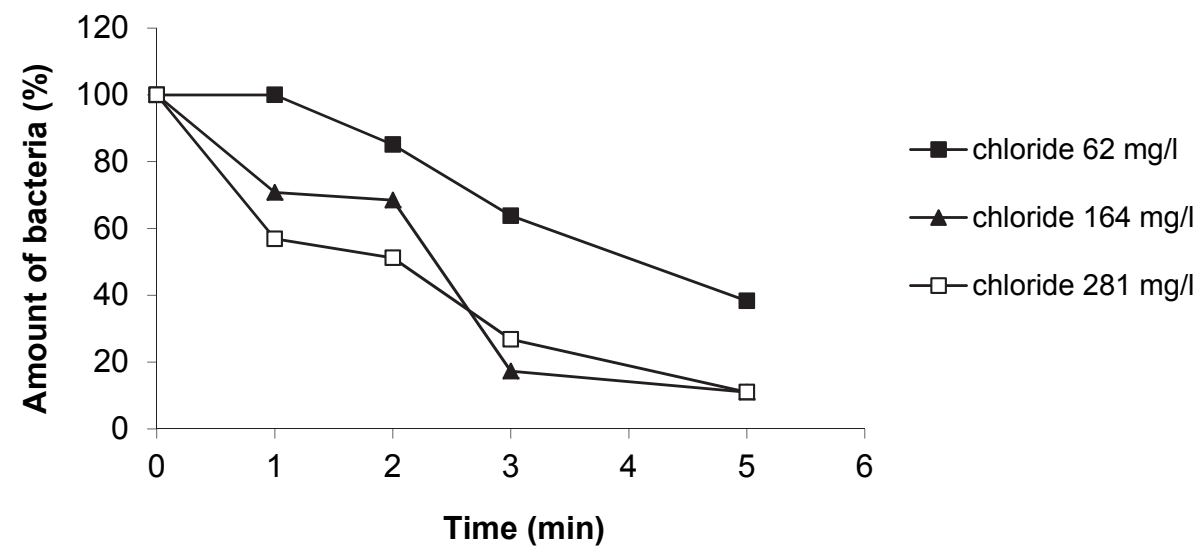

Figure 19. Inactivation efficiency of anaerobic bacteria during experiments with different initial chloride concentrations in wastewater (current density $42.9 \mathrm{~mA} / \mathrm{cm}^{2}$ ) (Data from Paper III)

\subsection{Electrochemical oxidation of sulphide}

Figure 20 shows the change in sulphide concentration in paper mill wastewater by EO. It was clearly seen that the oxidation of sulphide occurred in all cases. It was possible to achieve an almost $100 \%$ reduction with all the different initial sulphide concentrations. Yet at a lower initial concentration (4.0 $\mathrm{mg} / \mathrm{L}$ ) the adequate level of sulphide in wastewater was achieved with a smaller electric charge.

The effect of current density on sulphide removal efficiency is shown in Figure 21. The initial sulphide concentration was ca. $20 \mathrm{mg} / \mathrm{L}$ in all the experiments. The best electric charge efficiency was achieved with the lowest current density. Other current densities were not as effective and it was noted that the energy consumption of the effective treatment was higher. Other experiments of this study showed that $\mathrm{pH}$ did not change much during the experiments and the redox potential as well as dissolved oxygen values raised which proofs that oxidation of sulphide was mainly occurred by electrochemically generated oxygen. 


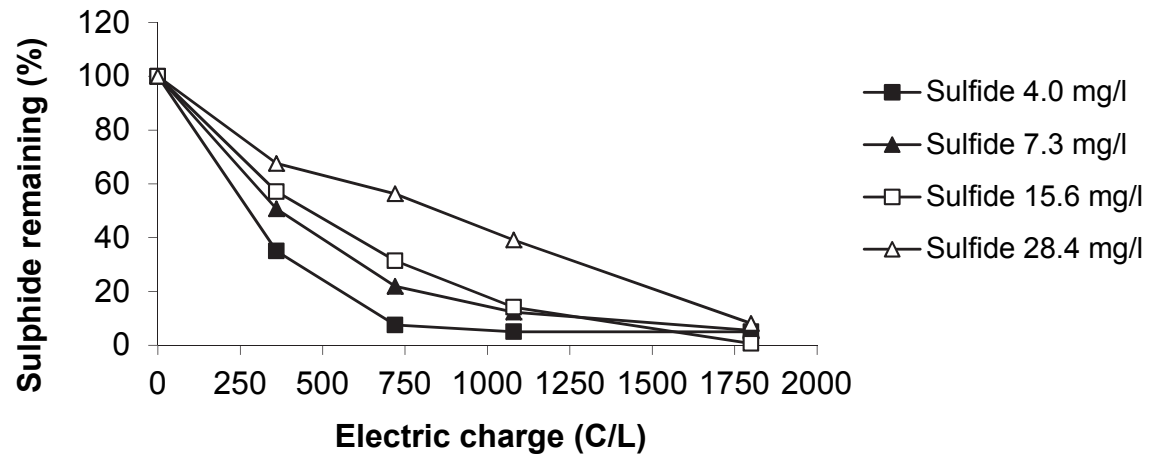

Figure 20. Electrochemical oxidation of sulphide in pulp and paper mill wastewater using an MMO electrode and different initial sulphide concentrations (current density $\left.42.9 \mathrm{~mA} / \mathrm{cm}^{2}\right)$ (Data from Paper III)

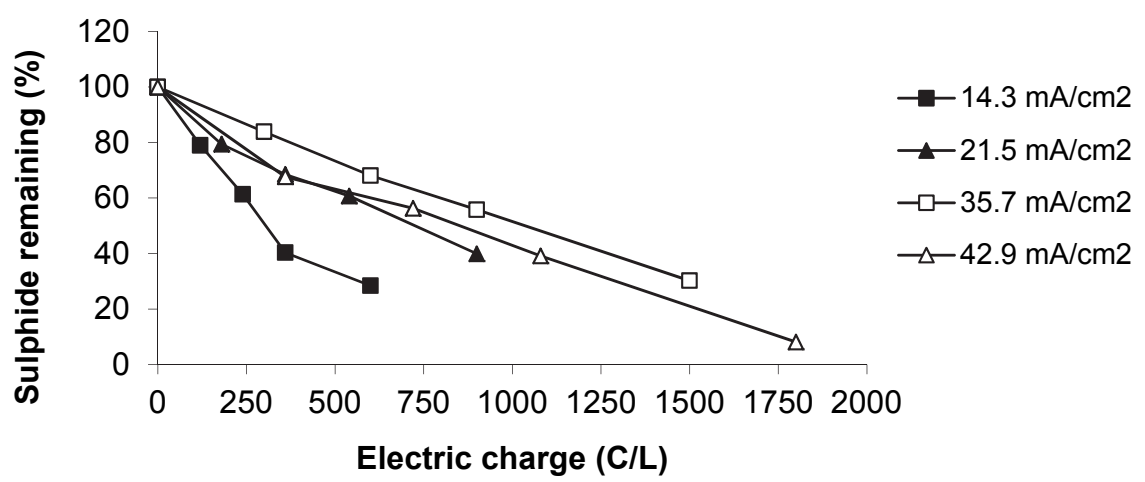

Figure 21. Electrochemical oxidation of sulphide in pulp and paper mill wastewater using an MMO electrode and different current densities with initial sulphide concentration of ca. $20 \mathrm{mg} / \mathrm{L}$ (Data from Paper III) 
In earlier studies EO has been used for the oxidation of sulphide containing waters [159-160]. It was found that sulphides were oxidized to elemental sulphur and sulphate during electrochemical treatment [159].

\subsection{Electrochemical oxidation of organics in pulp and paper mill bleaching effluent}

In paper VI the MMO and BDD electrodes were employed in electrochemical oxidation of the pulp and paper mill bleaching effluents. The method was rather effective in resin acid degradation in the treatment of the mill B effluent by MMO electrode. At a constant $\mathrm{pH}$ of 7.0 and 60 minutes of treatment time, the removal of abietic acid, $\beta$-sitosterol and oleic acid were $51 \%, 83 \%$ and $76 \%$, respectively. About $28 \%$ of COD could be removed. Compared to other techniques used in the study (such as chemical precipitation), removal rates were rather low. However, in this study continuous circulation of the wastewater was used through the experiments. Comparable study has shown better purification results for COD [161] but it was done in batch mode. This study showed also that MMO electrode was more effective in degradation efficiency of organic material than BDD electrode most likely due to active chlorine produced during the treatment. Jeong et al. [127] also observed that active chlorine was produced more on DSA electrodes than on BDD electrode. Yet electrochemical oxidation seems capable of removing wood extractives which are hazardous in a biological wastewater treatment process. If the method is used as a pre-treatment, potential inhibition of the biological treatment can be eliminated due to reduced toxicity in the primary effluent.

\subsection{Electrochemical degradation of methyl orange dye}

Textile industry dye was selected as a refractory organic compound for further analysis to see effectiveness of MMO and BDD electrodes. Methyl orange (MO) was selected as the model azoic dye since it is persistent and highly soluble in water; therefore its removal is also a subject of major 
importance in environmental protection. It was necessary to gain insight the electrochemical mineralization of $\mathrm{MO}$ in relatively high initial concentrations on BDD and MMO electrodes.

It was observed that MO dye degradation was more effective on a BDD electrode than on an MMO electrode (Paper V). For instance, at a current density of $50 \mathrm{~mA} / \mathrm{cm}^{2}$, the colour was almost completely removed on BDD after 90 minutes of treatment, while for the MMO electrode the removal ratio was less than $15 \%$. It was noticed that the BDD electrode has higher onset potential for oxygen evolution than the MMO electrode which indicates that the former has a much higher current efficiency.

The degradation on two electrodes presented different trends on the operative parameters. High current density enhanced the decolourization on both electrodes, but the promotion was not as significant on $\mathrm{MMO}$ as on $\mathrm{BDD}$, leading to a sharp increase in specific energy consumption. The decolourization of MO was more successful under acidic conditions for both electrodes but the $\mathrm{pH}$ dependence was not as obvious on $\mathrm{BDD}$ as on $\mathrm{MMO}$. The presence of $\mathrm{NaCl}$ favoured the indirect oxidation of active chlorine on the MMO electrode, which greatly improved the decolourization rate. The presence of $\mathrm{NaCl}$ promoted the decolourization also on BDD electrode, as also combustion rate of dye on both electrodes. The formation of active chlorines seemed to be more efficient on the MMO electrode. Oxygen evolution potential on BDD is much higher than on MMO electrode, which prevents the side reactions and greatly improves the current efficiency for hydroxyl radical formation $[43,162]$. High initial concentration enhanced the general current efficiency (GCE), though the COD and TOC removal efficiency was reduced.

In general, EO treatment of MO dye was more effective by BDD electrode in tested conditions. BDD performed better in relative wide concentration ranges and effect of $\mathrm{pH}$ was not so important for 
decolourization efficiency of dye. Moreover, BDD demonstrated more economical way for dye mineralization from the technical point of view, even absence of $\mathrm{NaCl}$. 


\section{CONCLUSIONS AND FURTHER RESEARCH}

Electrochemical oxidation was an effective method for inactivation of different biofilm and sulphide forming bacteria species in pulp and paper mill circulating waters and wastewaters. Paper mill bacteria (Deinococcus geothermalis, Pseudoxanthomonas taiwanensis and Meiothermus silvanus) were inactivated effectively $\left(>2 \log\right.$ ) at the MMO electrode with a current density of $50 \mathrm{~mA} / \mathrm{cm}^{2}$ and contact time of three minutes and the oxidation was mainly due to indirect electrochemical oxidation (electrochemical formation of chlorine/hypochlorite).

Increasing current density and initial chloride concentration of synthetic paper mill water speeded up inactivation. The initial $\mathrm{pH}$ value of the synthetic paper mill water did not have a significant impact on the inactivation rate. Bacteria species varied in response to different oxidants. Optimising the operative parameters is important in finding the best current efficiency for inactivation.

Electrochemical oxidation showed promising performance in oxidizing the sulphide present in paper mill wastewater. Inactivation of the anaerobic bacteria present in the wastewater was also observed. This supports strongly use of technique in oxidizing sulphide containing wastewaters or preventing sulphate reduction by anaerobic bacteria.

Based on the $\mathrm{CV}$ runs it was observed that hydrogen peroxide could be degraded to radicals with cathodic potentials used in this study in the synthetic paper mill water. The stainless steel electrode was more reactive than the MMO electrode on cathodic treatment. More reactive behaviour of SS 2343 electrode must be due to its surface structure which would offer great opportunity for biofilm prevention on stainless steel pipe lines at paper mills.

EO treatment of organics in bleaching effluent gave rather good results for resin acid degradation but COD removal was not as effective most likely due to continuous flow system used in the study. Electrochemical oxidation seemed capable of removing wood extractives which are hazardous in a 
biological wastewater treatment process. If the method is used as a pre-treatment, potential inhibition of the biological treatment can be eliminated due to reduced toxicity in the primary effluent.

EO treatment of MO dye (colour removal) was more effective by BDD electrode in tested conditions than by MMO electrode. It was observed that the BDD electrode had higher onset potential for oxygen evolution than the MMO electrode which indicated that the former had a much higher current efficiency for dye degradation.

The efficiency of the EO process largely depended on cell configuration, electrode material, electrolyte composition, the micro-organism or pollutant, and other experimental parameters, such as current density or the temperature of the treated water. Effective EO treatment of primary biofilm forming bacteria species will offer an alternative to biocides. In addition, combined treatment with hydrogen peroxide will produce powerful oxidants (radicals) which are effective but still environmentally friendly in paper mill environment. In future studies, it would be important to measure different radical reactions at the surface of the anode and by-products formed after the treatment.

Finding an effective and stable yet economical electrode material would speed up the use of EO technique in wastewater treatment. It would also be important to develop some novel electric power source for the system, such as solar energy. Combining treatment with current tertiary techniques would enhance the purification results. Also economical calculations of EO technique in treatment of different pulp and paper mill circulating waters and wastewaters would be needed. 


\section{REFERENCES}

[1] Thompson, G., Swain, J., Kay, M., Forster, C.F., The treatment of pulp and paper mill effluent: a review, Bioresource Technology 77 (2001) 275-286.

[2] Buyukkamaci, N., Koken, E., Economic evaluation of alternative wastewater treatment plant options for pulp and paper industry, Science of the Total Environment 408 (2010) 6070-6078.

[3] Pokhrel, D., Viraraghavan, T., Treatment of pulp and paper mill wastewater - a review, Science of the Total Environment, 333 (2004) 37-58.

[4] Ali, M., Sreekrishnan, T.R., Aquatic toxicity from pulp and paper mill effluents: a review, Advances in Environmental Research 5 (2001) 175-196.

[5] Singhal, A., Thakur, I.S., Decolourization and detoxification of pulp and paper mill effluent by Emericella nidulans var. nidulans, Journal of Hazardous Materials 171 (2009) 619-625.

[6] Lacorte, S., Latorre, A., Barcelo, D., Rigol, A., Malmqvist, A., Welander, T., Organic compounds in paper-mill process waters and effluents, Trends in Analytical Chemistry 22 (2003) 725-737.

[7] Kokkonen, R., Siren, H., Kauliomäki, S., Rovio, S., Luomanperä, K., On-line process monitoring of water-soluble ions in pulp and paper machine waters by capillary electrophoresis, Journal of Chromatography A 1032 (2004) 243-252.

[8] Latorre, A., Malmqvist, A., Lacorte, S., Welander, T., Barcelo, D., Evaluation of the treatment efficiencies of paper mill whitewaters in terms of organic composition and toxicity, Environmental Pollution 147 (2007) 648-655. 
[9] Latorre, A., Rigol, A., Lacorte, S., Barcelo, D., Comparison of gas chromatography-mass spectrometry and liquid chromatography-mass spectrometry for the determination of fatty and resin acids in paper mill process waters, Journal of Chromatography A 991 (2003) 205-215.

[10] Klahre, J., Flemming, H.-C., Monitoring of biofouling in papermill process waters, Water Research 34 (2000) 3657-3665.

[11] Oppong, D., King, V.M., Bowen, J.A., Isolation and characterization of filamentous bacteria from paper mill slimes, International Biodeterioration \& Biodegradation 52 (2003) 53-62.

[12] Väisänen, O.M., Weber, A., Bennasar, A., Rainey, F.A., Busse, H.-J., Salkinoja-Salonen, M.S., Microbial communities of printing paper machines, Journal of Applied Microbiology 84 (1998) 10691084.

[13] Peltola, M., Kuosmanen, T., Sinkko, H., Vesalainen, N., Pulliainen, M., Korhonen, P., ParttiPellinen, K., Räsänen, J.P., Rintala, J., Kolari, M., Rita, H., Salkinoja-Salonen, M., Effects of polarization in the presence and absence of biocides on biofilms in a simulated paper machine water, Journal of Industrial and Microbiological Biotechnology 38 (2011) 1719-1727.

[14] Suihko, M.-L., Sinkko, H., Partanen, L., Mattila-Sandholm, T., Salkinoja-Salonen, M., Raaska, L., Description of heterotrophic bacteria occurring in paper mills and paper products, Journal of Applied Microbiology 97 (2004) 1228-1235.

[15] Ekman, J., Kosonen, M., Jokela, S., Kolari, M., Korhonen, P., Salkinoja-Salonen, M., Detection and quantitation of colored deposit-forming Meiothermus spp. in paper industry processes and end products, Journal of Industrial Microbiology \& Biotechnology 34 (2007) 203-211. 
[16] Kolari, M., Nuutinen, J., Salkinoja-Salonen, M.S., Mechanisms of biofilm formation in paper machine by Bacillus species: the role of Deinococcus geothermalis, Journal of Industrial Microbiology \& Biotechnology 27 (2001) 343-351.

[17] Kolari, M., Schmidt, U., Kuismanen, E., Salkinoja-Salonen, M.S., Firm but Slippery Attachment of Deinococcus Geothermalis, Journal of Bacteriology 184 (2002) 2473-2480.

[18] Rohella, R.S., Choudhury, S., Manthan, M., Murthy, J.S., Removal of colour and turbidity in pulp and paper mill effluents using polyelectrolytes, Indian Journal of Environmental Health 43 (2001) 159-163.

[19] Yen, N.T., Oanh, N.T.K., Reutergard, L.B., Wise, D.L., Lan, L.T.T., An integrated waste survey and environmental effects of COGIDO, a bleached pulp and paper mill in Vietnam on the receiving water body, Global Environmental Biotechnology 66 (1996) 349-364.

[20] Mandal, T.N., Bandana, T.N., Studies on physicochemical and biological characteristics of pulp and paper mill effluents and its impact on human beings, Journal of Freshwater Biology 8 (1996) 191-196.

[21] Gupta, A., Pollution load of paper mill effluent and its impact on biological environment, Journal of Ecotoxicology and Environmental Monitoring 7 (1997) 101-112.

[22] Dutta, S.K., Study of the physicochemical properties of effluents of the paper mill that affected the paddy plants, Journal of Environmental Pollution 6 (1999) 181-188.

[23] Emamjomeh, M.M., Sivakumar, M., Review of pollutants removed by electrocoagulation and electrocoagulation/flotation processes, Journal of Environmental Management 90 (2009) 1663-1679.

[24] Ben Mansour, L., Ksentini, I., Elleuch, B., Treatment of wastewaters of paper industry by coagulation-electroflotation, Desalination 208 (2007) 34-41. 
[25] Beril Gönder, Z.B., Arayici, S., Barlas, H., Advanced treatment of pulp and paper mill wastewater by nanofiltration process: Effects of operating conditions on membrane fouling, Separation and Purification Technology 76 (2011) 292-302.

[26] Pizzichini, M., Russo, C., Di Meo, C., Purification of pulp and paper wastewater, with membrane technology, for water reuse in a closed loop, Desalination 178 (2005) 351-359.

[27] Tavares, C.R., Vieira, M., Petrus, J.C.C., Bortoletto, E.C., Ceravollo, F., Ultrafiltration/complexation process for metal removal from pulp and paper industry wastewater, Desalination 144 (2002) 261-265.

[28] Wong, S.S., Teng, T.T., Ahmad, A.L., Zuhairi, A., Najafpour, G., Treatment of pulp and paper mill wastewater by polyacrylamide (PAM) in polymer induced flocculation, Journal of Hazardous Materials B135 (2006) 378-388.

[29] Wang, J.-P., Chen, Y.-Z., Wang, Y., Yuan, S.-J., Yu, H.-Q., Optimization of the coagulationflocculation process for pulp mill wastewater treatment using a combination of uniform design and response surface methodology, Water Research 45 (2011) 5633-5640.

[30] Rodrigues, A.C., Boroski, M., Shimada, N.S., Garcia, J.C., Nozaki, J., Hioka, N., Treatment of paper pulp and paper mill wastewater by coagulation-flocculation followed by heterogeneous photocatalysis, Journal of Photochemistry and Photobiology A: Chemistry 194 (2008) 1-10.

[31] Zhang, Q., Chuang, K.T., Adsorption of organic pollutants from effluents of a Kraft pulp mill on activated carbon and polymer resin, Advances in Environmental Research 3 (2001) 251-258.

[32] Catalkaya, E.C., Kargi, F., Advanced oxidation treatment of pulp mill effluent for TOC and toxicity removals, Journal of Environmental Management 87 (2008) 396-404. 
[33] Catalkaya, E.C., Kargi, F., Color, TOC and AOX removals from pulp mill effluent by advanced oxidation processes: A comparative study, Journal of Hazardous Materials B139 (2007) 244-253.

[34] Amat, A.M., Arques, A., Lopez, F., Miranda, M.A., Solar photo-catalysis to remove paper mill wastewater pollutants, Solar Energy 79 (2005) 393-401.

[35] Lucas, M.S., Peres, J.A., Amor, C., Prieto-Rodriquez, L., Maldonado, M.I., Tertiary treatment of pulp mill wastewater by solar photo-Fenton, Journal of Hazardous Materials 225-226 (2012) 173-181.

[36] Balcioglu, I.A., Tarlan, E., Kivilcimdan, C., Turker Sacan, M., Merits of ozonation and catalytic ozonation pre-treatment in the algal treatment of pulp and paper mill effluents, Journal of Environmental Management 85 (2007) 918-926.

[37] Fontanier, V., Farines, V., Albet, J., Baig, S., Molinier, J., Study of catalyzed ozonation for advanced treatment of pulp and paper mill effluents, Water Research 40 (2006) 303-310.

[38] Mänttäri, M., Kuosa, M., Kallas, J., Nyström, M., Membrane filtration and ozone treatment of biologically treated effluents from the pulp and paper industry, Journal of Membrane Science 309 (2008) 112-119.

[39] Vepsäläinen, M., Selin, J., Pulliainen, M., Sillanpää, M., Combined electrocoagulation and chemical coagulation of paper mill mechanically cleaned water, Journal of Pulp and Paper Science 33 (2007) 233-239.

[40] Vepsäläinen, M., Selin, J., Rantala, P., Pulliainen, M., Särkkä, H., Kuhmonen, K., Bhatnagar, A., Sillanpää, M., Precipitation of dissolved sulphide in pulp and paper mill wastewater by electrocoagulation, Environmental Technology 32 (2011) 1393-1400. 
[41] Vepsäläinen, M., Kivisaari, H., Pulliainen, M., Oikari, A., Sillanpää, M., Removal of toxic pollutants from pulp mill effluents by electrocoagulation, Separation and Purification Technology 81 (2011) 141-150.

[42] Stoica, A., Sandberg, M., Holby, O., Energy use and recovery strategies within wastewater treatment and sludge handling at pulp and paper mills, Bioresource Technology 100 (2009) 3497 3505.

[43] Chen, G., Electrochemical technologies in wastewater treatment, Separation and Purification Technology 38 (2004) 11-41.

[44] Mollah, M.Y.A., Morkovsky, P., Gomez, J.A.G., Kesmez, M., Parga, J., Cocke, D.L., Fundamentals, present and future perspectives of electrocoagulation, Journal of Hazardous Materials B114 (2004) 199-210.

[45] Holt, P.K., Barton, G.W., Mitchell, C.A., The future for electrocoagulation as a localised water treatment technology, Chemosphere 59 (2005) 355-367.

[46] Pham, A.T., Sillanpää, M., Isosaari, P., Sewage Sludge Electro-Dewatering Treatment - A Review, Drying Technology 30 (2012) 691-706.

[47] Oonnittan, A., Shrestha, R.A., Sillanpää, M., Removal of hexachlorobenzene from soil by electrokinetically enhanced chemical oxidation, Journal of Hazardous Materials 162 (2009) 989-993.

[48] Oonnittan, A., Isosaari, P., Sillanpää, M., Oxidant availability in soil and its effect on HCB removal during electrokinetic Fenton process, Separation and Purification Technology 76 (2010) 146150. 
[49] Pham, T.D., Shrestha, R.A., Virkutyte, J., Sillanpää, M., Combined ultrasonication and electrokinetic remediation for persistent organic removal from contaminated kaolin, Electrochimica Acta 54 (2009) 1403-1407.

[50] Pham, T.D., Shrestha, R.A., Sillanpää, M., Electrokinetic and Ultrasonic Treatment of Kaolin Contaminated by POPs, Separation Science and Technology 44 (2009) 2410-2420.

[51] Martinez-Huitle, C.A., Brillas, E., Decontamination of wastewaters containing synthetic organic dyes by electrochemical methods: A general review, Applied Catalysis B: Environmental 87 (2009) $105-145$.

[52] Sires, I., Brillas, E., Remediation of water pollution caused by pharmaceutical residues based on electrochemical separation and degradation technologies: A review, Environment International 40 (2012) 212-229.

[53] Kapalka, A., Foti, G., Comninellis, C., Chapter 1 Basic Principles of the Electrochemical Mineralization of Organic Pollutants for Wastewater Treatment, In: Comninellis, C., Chen, G. (Eds), Electrochemistry for the Environment, Springer, New York, USA, 2010, p. 1-23.

[54] Rajkumar, D, Kim, J.G., Oxidation of various reactive dyes with in situ electro-generated active chlorine for textile dyeing industry wastewater treatment, Journal of Hazardous Materials B136 (2006) 203-212.

[55] Rajkumar, D., Song, B.J., Kim, J.G., Electrochemical degradation of Reactive Blue 19 in chloride medium for the treatment of textile dyeing wastewater with identification of intermediate compounds, Dyes and Pigments 72 (2007) 1-7. 
[56] Kraft, A., Stadelmann, M., Blaschke, M., Kreysig, D., Sandt, B., Schröder, F., Rennau, J., Electrochemical water disinfection part I: hypochlorite production from very dilute chloride solutions, Journal of Applied Electrochemistry 29 (1999) 861-868.

[57] Bergmann, M.E.H., Koparal, A.S., Studies on electrochemical disinfectant production using anodes containing $\mathrm{RuO}_{2}$, Journal of Applied Electrochemistry 35 (2005) 1321-1329.

[58] Chatzisymeon, E., Xekoukoulotakis, N.P., Coz, A., Kalogerakis, N., Mantzavinos, D., Electrochemical treatment of textile dyes and dyehouse effluents, Journal of Hazardous Materials B137 (2006) 998-1007.

[59] Sakalis, A., Fytianos, K., Nickel, U., Voulgaropoulos, A., A comparative study of platinised titanium and niobe/synthetic diamond as anodes in the electrochemical treatment of textile wastewater, Chemical Engineering Journal 119 (2006) 127-133.

[60] Gotsi, M., Kalogerakis, N., Psillakis, E., Samaras, P., Mantzavinos, D., Electrochemical oxidation of olive oil mill wastewaters, Water Research 39 (2005) 4177-4187.

[61] Polcaro, A.M., Vacca, A., Mascia, M., Palmas, S., Pompei, R., Laconi, S., Characterization of a stirred tank electrochemical cell for water disinfection processes, Electrochimica Acta 52 (2007) 2595-2602.

[62] Dhaouadi, A., Monser, L., Adhoum, N., Anodic oxidation and electro-Fenton treatment of rotenone, Electrochimica Acta 54 (2009) 4473-4480.

[63] Chu, Y.Y., Qian, Y., Wang, W.J., Deng, X.L., A dual-cathode electro-Fenton oxidation coupled with anodic oxidation system used for 4-nitrophenol degradation, Journal of Hazardous Materials 199-200 (2012) 179-185. 
[64] Guinea, E., Garrido, J.A., Rodriguez, R.M., Cabot, P.-L., Arias, C., Centellas, F., Brillas, E., Degradation of the fluoroquinolone enrofloxacin by electrochemical advanced oxidation processes based on hydrogen peroxide electrogeneration, Electrochimica Acta 55 (2010) 2101-2115.

[65] Martins, A.F., Wilde, M.L., Vasconcelos, T.G., Henriques, D.M., Nonylphenol polyethoxylate degradation by means of electrocoagulation and electrochemical Fenton, Separation and Purification Technology 50 (2006) 249-255.

[66] Zhao, X., Zhang, B., Liu, H., Chen, F., Li, A., Qu, J., Transformation characteristics of refractory pollutants in plugboard wastewater by an optimal electrocoagulation and electro-Fenton process, Chemosphere 87 (2012) 631-636.

[67] El-Ashtoukhy, E.-S.Z., Amin, N.K., Abdelwahab, O., Treatment of paper mill effluents in a batch-stirred electrochemical tank reactor, Chemical Engineering Journal 146 (2009) 205-210.

[68] Hamza, M., Ammar, S., Abdelhedi, R., Electrochemical oxidation of 1,3,5-trimethoxybenzene in aqueous solutions at gold oxide and lead dioxide electrodes, Electrochimica Acta 56 (2011) 37853789.

[69] Awad, H.S., Abo Galwa, N., Electrochemical degradation of Acid Blue and Basic Brown dyes on $\mathrm{Pb} / \mathrm{PbO}_{2}$ electrode in the presence of different conductive electrolyte and effect of various operating factors, Chemosphere 61 (2005) 1327-1335.

[70] Flox, C., Arias, C., Brillas, E., Savall, A., Groenen-Serrano, K., Electrochemical incineration of cresols: A comparative study between $\mathrm{PbO}_{2}$ and boron-doped diamond anodes, Chemosphere 74 (2009) 1340-1347. 
[71] Tavares, M.G., da Silva, L.V.A., Sales Solano, A.M., Tonholo, J., Martinez-Huitle, C.A., Zanta, C.L.P.S., Electrochemical oxidation of Methyl Red using $\mathrm{Ti} / \mathrm{Ru}_{0.3} \mathrm{Ti}_{0.7} \mathrm{O}_{2}$ and $\mathrm{Ti} / \mathrm{Pt}$ anodes, Chemical Engineering Journal 204-206 (2012) 141-150

[72] Wang, B., Kong, W., Ma, H., Electrochemical treatment of paper mill wastewater using threedimensional electrodes with $\mathrm{Ti} / \mathrm{Co} / \mathrm{SnO}_{2}-\mathrm{Sb}_{2} \mathrm{O}_{5}$ anode, Journal of Hazardous Materials 146 (2007) 295-301.

[73] Qu, X., Gao, W.J., Han, M.N., Chen, A., Liao, B.Q., Integrated thermophilic submerged aerobic membrane bioreactor and electrochemical oxidation for pulp and paper effluent treatment - towards system closure, Bioresource Technology 116 (2012) 1-8.

[74] Miwa, D.W., Malpass, G.R.P, Machado, S.A.S., Motheo, A.J., Electrochemical degradation of carbaryl on oxide electrodes, Water Research 40 (2006) 3281-3289.

[75] Patel, U.D., Suresh, S., Electrochemical treatment of pentachlorophenol in water and pulp bleaching effluent, Separation and Purification Technology 61 (2008) 115-122.

[76] Wang, B., Gu, L., Ma, H., Electrochemical oxidation of pulp and paper making wastewater assisted by transition metal modified kaolin, Journal of Hazardous Materials 143 (2007) 198-205.

[77] Ma, H., Wang, B., Wang, Y., Application of molybdenum and phosphate modified kaolin in electrochemical treatment of paper mill wastewater, Journal of Hazardous Materials 145 (2007) 417423.

[78] Montilla, F., Michaud, P.A., Morallon, E., Vazquez, J.L., Comninellis, C., Electrochemical oxidation of benzoic acid at boron-doped diamond electrodes, Electrochimica Acta 47 (2002) 35093513. 
[79] Kraft, A., Stadelmann, M., Blaschke, M., Anodic oxidation with doped diamond electrodes: a new advanced oxidation process, Journal of Hazardous Materials B103 (2003) 247-261.

[80] Rodrigo, M.A., Cañizares, P., Sanchez-Carretero, A., Saez, C., Use of conductive-diamond electrochemical oxidation for wastewater treatment, Catalysis Today 151 (2010) 173-177.

[81] Panizza, M., Cerisola, G., Application of diamond electrodes to electrochemical processes, Electrochimica Acta 51 (2005) 191-199.

[82] Chen, X., Chen, G., Chapter 15, Fabrication and Application of Ti/BDD for Wastewater Treatment, In: Brillas, E., Martinez-Huitle, C. A., (Eds), Synthetic Diamond Films: Preparation, Electrochemistry, Characterization, and Applications, John Wiley \& Sons, Inc., New Jersey, USA, 2011, p. 353-371.

[83] Faouzi, A.M., Nasr, B., Abdellatif, G., Electrochemical degradation of anthraquinone dye Alizarin Red S by anodic oxidation on boron-doped diamond, Dyes and Pigments 73 (2007) 86-89.

[84] Chen, X., Chen, G., Anodic oxidation of Orange II on Ti/BDD electrode: Variable effects, Separation and Purification Technology 48 (2006) 45-49.

[85] Migliorini, F.L., Braga, N.A., Alves, S.A., Lanza, M.R.V., Baldan, M.R., Ferreira, N.G., Anodic oxidation of wastewater containing the Reactive Orange 16 Dye using heavily boron-doped diamond electrodes, Journal of Hazardous Materials 192 (2011) 1683-1689.

[86] Ma, H., Zhuo, Q., Wang, B., Electro-catalytic degradation of methylene blue wastewater assisted by $\mathrm{Fe}_{2} \mathrm{O}_{3}$-modified kaolin, Chemical Engineering Journal 155 (2009) 248-253.

[87] Andrade, L.S., Tasso, T.T., da Silva, D.L., Rocha-Filho, R.C., Bocchi, N., Biaggio, S.R., On the performance of lead dioxide and boron-doped diamond electrodes in the anodic oxidation of 
simulated wastewater containing the Reactive Orange 16 dye, Electrochimica Acta 54 (2009) 20242030.

[88] Tsantaki, E., Velegraki, T., Katsaounis, A., Mantzavinos, D., Anodic oxidation of textile dyehouse effluents on boron-doped diamond electrode, Journal of Hazardous Materials 207-208 (2012) 91-96.

[89] Song, S., Fan, J., He, Z., Zhan, L., Liu, Z., Chen, J., Xu, X., Electrochemical degradation of azo dye C.I. Reactive Red 195 by anodic oxidation on $\mathrm{Ti} / \mathrm{SnO}_{2}-\mathrm{Sb} / \mathrm{PbO}_{2}$ electrodes, Electrochimica Acta 55 (2010) 3606-3613.

[90] Ramirez, C., Saldana, A., Hernandez, B., Acero, R., Guerra, R., Garcia-Segura, S., Brillas, E., Peralta-Hernandez, J.M., Electrochemical oxidation of methyl orange azo dye at pilot flow plant using BDD technology, Journal of Industrial and Engineering Chemistry 19 (2013) 571-579.

[91] Garcia-Morales, M.A., Roa-Morales, G., Barrera-Diaz, C., Bilyeu, B., Rodrigo, M.A., Synergy of electrochemical oxidation using boron-doped diamond (BDD) electrodes and ozone $\left(\mathrm{O}_{3}\right)$ in industrial wastewater treatment, Electrochemistry Communications 27 (2013) 34-37.

[92] Xu, L., Du, L.-S., Wang, C., Xu, W., Nanofiltration coupled with electrolytic oxidation in treating simulated dye wastewater, Journal of Membrane Science 409-410 (2012) 329-334.

[93] Park, H., Choo, K.-H., Park, H.-S., Choi, J., Hoffmann, M.R., Electrochemical oxidation and microfiltration of municipal wastewater with simultaneous hydrogen production: Influence of organic and particulate matter, Chemical Engineering Journal 215-216 (2013) 802-810.

[94] Senthilkumar, S., Ahmed Basha, C., Perumalsamy, M., Prabhu, H.J., Electrochemical oxidation and aerobic biodegradation with isolated bacterial strains for dye wastewater: Combined and integrated approach, Electrochimica Acta 77 (2012) 171-178. 
[95] Gonçalves, M.R., Marques, I.P., Correia, J.P., Electrochemical mineralization of anaerobically digested olive mill wastewater, Water Research 46 (2012) 4217-4225.

[96] Chen, F., Yu, S., Dong, X., Zhang, S., High-efficient treatment of wastewater contained the carcinogen naphthylamine by electrochemical oxidation with $\gamma-\mathrm{Al}_{2} \mathrm{O}_{3}$ supported $\mathrm{MnO}_{2}$ and $\mathrm{Sb}$-doped $\mathrm{SnO}_{2}$ catalyst, Journal of Hazardous Materials 227-228 (2012) 474-479.

[97] Tissot, G.B., Anglada, A., Dimitriou-Christidis, P., Rossi, L., Samuel Arey, J., Comninellis, Ch., Kinetic experiments of electrochemical oxidation of iohexol on BDD electrodes for wastewater treatment, Electrochemistry Communications 23 (2012) 48-51.

[98] Bagastyo, A.Y., Batstone, D.J., Kristiana, I., Gernjak, W., Joll, C., Radjenovic, J., Electrochemical oxidation of reverse osmosis concentrate on boron-doped diamond anodes at circumneutral and acidic pH, Water Research 46 (2012) 6104-6112.

[99] Bagastyo, A.Y., Batstone, D.J., Rabaey, K., Radjenovic, J., Electrochemical oxidation of electrodialysed reverse osmosis concentrate on $\mathrm{Ti} / \mathrm{Pt}-\mathrm{IrO}_{2}-\mathrm{Sb}$ and boron-doped diamond electrodes, Water Research 47 (2013) 242-250.

[100] Panizza, M., Cerisola, G., Olive mill wastewater treatment by anodic oxidation with parallel plate electrodes, Water Research 40 (2006) 1179-1184.

[101] Chatzisymeon, E., Dimou, A., Mantzavinos, D., Katsaounis, A., Electrochemical oxidation of model compounds and olive mill wastewater over DSA electrodes: 1 . The case of $\mathrm{Ti} / \mathrm{IrO}_{2}$ anode, Journal of Hazardous Materials 167 (2009) 268-274.

[102] Brillas, E., Sires, I., Arias, C., Cabot, P.L., Centellas, F., Rodriguez, R.M., Garrido, J.A., Mineralization of paracetamol in aqueous medium by anodic oxidation with a boron-doped diamond electrode, Chemosphere 58 (2005) 399-406. 
[103] Szpyrkowicz, L., Kaul, S.N., Neti, R.N., Satyanarayan, S., Influence of anode material on electrochemical oxidation for the treatment of tannery wastewater, Water Research 39 (2005) 16011613.

[104] Li, X.-Y., Cui, Y.-H., Feng, Y.-J., Xie, Z.-M., Gu, J.-D., Reaction pathways and mechanisms of the electrochemical degradation of phenol on different electrodes, Water Research 39 (2005) 19721981.

[105] Zhu, X., Ni, J., Lai, P., Advanced treatment of biologically pretreated coking wastewater by electrochemical oxidation using boron-doped diamond electrodes, Water Research 43 (2009) 4347 4355.

[106] Chu, Y.-Y., Wang, W.-J., Wang, M., Anodic oxidation process for the degradation of 2,4dichlorophenol in aqueous solution and the enhancement of biodegradability, Journal of Hazardous Materials 180 (2010) 247-252.

[107] Pikaar, I., Rozendal, R.A., Yuan, Z., Keller, J., Rabaey, K., Electrochemical sulfide oxidation from domestic wastewater using mixed metal-coated titanium electrodes, Water Research 45 (2011) $5381-5388$

[108] Murugananthan, M., Latha, S.S., Bhaskar Raju, G., Yoshihara, S., Anodic oxidation of ketoprofen-An anti-inflammatory drug using boron doped diamond and platinum electrodes, Journal of Hazardous Materials 180 (2010) 753-758.

[109] Choi, J.Y., Lee, Y.-J., Shin, J., Yang, J.-W., Anodic oxidation of 1,4-dioxane on boron-doped diamond electrodes for wastewater treatment, Journal of Hazardous Materials 179 (2010) 762-768.

[110] Cabeza, A., Urtiaga, A., Rivero, M.-J., Ortiz, I., Ammonium removal from landfill leachate by anodic oxidation, Journal of Hazardous Materials 144 (2007) 715-719. 
[111] Lissens, G., Pieters, J., Verhaege, M., Pinoy, L., Verstraete, W., Electrochemical degradation of surfactants by intermediates of water discharge at carbon-based electrodes, Electrochimica Acta 48 (2003) 1655-1663.

[112] Flox, C., Garrido, J.A., Rodriguez, R.M., Centellas, F., Cabot, P.-L., Arias, C., Brillas, E., Degradation of 4,6-dinitro-o-cresol from water by anodic oxidation with a boron-doped diamond electrode, Electrochimica Acta 50 (2005) 3685-3692.

[113] Wang, J., Farrell, J., Electrochemical Inactivation of Triclosan with Boron Doped Diamond Film Electrodes, Environmental Science and Technology 38 (2004) 5232-5237.

[114] Martin de Vidales, M.J., Saez, C., Cañizares , P., Rodrigo, M.A., Electrolysis of progesterone with conductive-diamond electrodes, Journal of Chemical Technology and Biotechnology 87 (2012) $1173-1178$

[115] Martin de Vidales, M.J., Robles-Molina, J., Dominguez-Romero, J.C., Cañizares, P., Saez, C., Molina-Diaz, A., Rodrigo, M.A., Removal of sulfamethoxazole from waters and wastewaters by conductive-diamond electrochemical oxidation, Journal of Chemical Technology and Biotechnology 87 (2012) 1441-1449.

[116] Robles-Molina, J., Martin de Vidales, M.J., Garcia-Reyes, J.F., Cañizares, P., Saez, C., Rodrigo, M.A., Molina-Diaz, A., Conductive-diamond electrochemical oxidation of chlorpyrifos in wastewater and identification of its main degradation products by LC-TOFMS, Chemosphere 89 (2012) 1169-1176.

[117] Li, X., Wang, C., Qian, Y., Wang, Y., Zhang, L., Simultaneous removal of chemical oxygen demand, turbidity and hardness from biologically treated citric acid wastewater by electrochemical oxidation for reuse, Separation and Purification Technology 107 (2013) 281-288. 
[118] Skoumal, M., Arias, C., Cabot, P.L., Centellas, F., Garrido, J.A., Rodriguez, R.M., Brillas, E., Mineralization of the biocide chloroxylenol by electrochemical advanced oxidation processes, Chemosphere 71 (2008) 1718-1729.

[119] Brillas, E., Garcia-Segura, S., Skoumal, M., Arias, C., Electrochemical incineration of diclofenac in neutral aqueous medium by anodic oxidation using Pt and boron-doped diamond anodes, Chemosphere 79 (2010) 605-612.

[120] Borras, N., Oliver, R., Arias, C., Brillas, E., Degradation of Atrazine by Electrochemical Advanced Oxidation Processes Using a Boron-Doped Diamond Anode, Journal of Physical Chemistry A 114 (2010) 6613-6621.

[121] Guinea, E., Centellas, F., Garrido, J.A., Rodriguez, R.M., Arias, C., Cabot, P.-L., Brillas, E., Solar photoassisted anodic oxidation of carboxylic acids in presence of $\mathrm{Fe}^{3+}$ using a boron-doped diamond electrode, Applied Catalysis B: Environmental 89 (2009) 459-468.

[122] Dominquez-Ramos, A., Aldaco, R., Irabien, A., Photovoltaic solar electrochemical oxidation (PSEO) for treatment of lignosulfonate wastewater, Journal of Chemical Technology and Biotechnology 85 (2010) 821-830.

[123] Guinea, E., Brillas, E., Centellas, F., Canizares, P., Rodrigo, M.A., Saez, C., Oxidation of enrofloxacin with conductive-diamond electrochemical oxidation, ozonation and Fenton oxidation. A comparison, Water Research 43 (2009) 2131-2138.

[124] Cañizares, P., Hernandez-Ortega, M., Rodrigo, M.A., Barrera-Diaz, C.E., Roa-Morales, G., Saez, C., A comparison between Conductive-Diamond Electrochemical Oxidation and other Advanced Oxidation Processes for the treatment of synthetic melanoidins, Journal of Hazardous Materials 164 (2009) 120-125. 
[125] Jeong, J., Kim, J.Y., Cho, M., Choi, W., Yoon, J., Inactivation of Escherichia coli in the electrochemical disinfection process using a Pt anode, Chemosphere 67 (2007) 652-659.

[126] Lopez-Galvez, F., Posada-Izquierdo, G.D., Selma, M.V., Perez-Rodriguez, F., Gobet, J., Gil, M.I., Allende, A., Electrochemical disinfection: An efficient treatment to inactivate Escherichia coli O157:H7 in process wash water containing organic matter, Food Microbiology 30 (2012) 146-156.

[127] Jeong, J., Kim, C., Yoon, J., The effect of electrode material on the generation of oxidants and microbial inactivation in the electrochemical disinfection processes, Water Research 43 (2009) 895901.

[128] Ma, Q., Liu, T., Tang, T., Yin, H., Ai, S., Drinking water disinfection by hemin-modified graphite felt and electrogenerated reactive oxygen species, Electrochimica Acta 56 (2011) 8278-8284.

[129] Fang, Q., Shang, C., Chen, G., MS2 Inactivation by Chloride-Assisted Electrochemical Disinfection, Journal of Environmental Engineering 132 (2006) 13-22.

[130] Drees, K.P., Abbaszadegan, M., Maier, R.M., Comparative electrochemical inactivation of bacteria and bacteriophage, Water Research 37 (2003) 2291-2300.

[131] Feng, C., Suzuki, K., Zhao, S., Sugiura, N., Shimada, S., Maekawa, T., Water disinfection by electrochemical treatment, Bioresource Technology 94 (2004) 21-25.

[132] Cano, A., Cañizares, P., Barrera-Diaz, C., Saez, C., Rodrigo, M.A., Use of conductive-diamond electrochemical-oxidation for the disinfection of several actual treated wastewaters, Chemical Engineering Journal 211-212 (2012) 463-469.

[133] Oh, B.S., Oh, S.G., Jung, Y.J., Hwang, Y.Y., Kang, J.-W., Kim, I.S., Evaluation of a seawater electrolysis process considering formation of free chlorine and perchlorate, Desalination and Water Treatment 18 (2010) 245-250. 
[134] Oh, B.S., Oh, S.G., Hwang, Y.Y., Yu, H.-W., Kang, J.-W., Kim, I.S., Formation of hazardous inorganic by-products during electrolysis of seawater as a disinfection process for desalination, Science of the Total Environment 408 (2010) 5958-5965.

[135] Bergmann, M.E.H., Rollin, J., Product and by-product formation in laboratory studies on disinfection electrolysis of water using boron-doped diamond anodes, Catalysis Today 124 (2007) 198-203.

[136] Tsolaki, E., Pitta, P., Diamadopoulos, E., Electrochemical disinfection of simulated ballast water using Artemia salina as indicator, Chemical Engineering Journal 156 (2010) 305-312.

[137] Mascia, M., Vacca, A., Palmas, S., Electrochemical treatment as a pre-oxidative step for algae removal using Chlorella vulgaris as a model organism and BDD anodes, Chemical Engineering Journal 219 (2013) 512-519.

[138] Frontistis, Z., Brebou, C., Venieri, D., Mantzavinos, D., Katsaounis, A., BDD anodic oxidation as tertiary wastewater treatment for the removal of emerging micropollutants, pathogens and organic matter, Journal of Chemical Technology and Biotechnology 86 (2011) 1233-1236.

[139] Li, X.Y., Ding, F., Lo, P.S.Y., Sin, S.H.P., Electrochemical Disinfection of Saline Wastewater Effluent, Journal of Environmental Engineering 128 (2002) 697-704.

[140] Schmalz, V., Dittmar, T., Haaken, D., Worch, E., Electrochemical disinfection of biologically treated wastewater from small treatment systems by using boron-doped diamond (BDD) electrodes Contribution for direct reuse of domestic wastewater, Water Research 43 (2009) 5260-5266.

[141] Li, H., Zhu, X., Ni, J., Inactivation of Escherichia coli in $\mathrm{Na}_{2} \mathrm{SO}_{4}$ electrolyte using boron-doped diamond electrode, Electrochimica Acta 56 (2010) 448-453. 
[142] Li, H., Zhu, X., Ni, J., Comparison of electrochemical method with ozonation, chlorination and monochloramination in drinking water disinfection, Electrochimica Acta 56 (2011) 9789-9796.

[143] Kolari, M., Nuutinen, J., Rainey F.A., Salkinoja-Salonen, M., Colored moderately thermophilic bacteria in paper-machine biofilms, Journal of Industrial Microbiology and Biotechnology 30 (2003) 225-238.

[144] Peltola, M., Kanto Öqvist, C., Ekman, J., Kosonen, M., Jokela, S., Kolari, M., Korhonen, P., Salkinoja-Salonen, M., Quantitative contributions of bacteria and of Deinococcus geothermalis to deposits and slimes in paper industry, Journal of Industrial Microbiology and Biotechnology 35 (2008) 1651-1657.

[145] Rasimus, S., Kolari M., Rita, H., Hoornstra, D., Salkinoja-Salonen, M., Biofilm-forming bacteria with varying tolerance to peracetic acid from a paper machine, Journal of Industrial Microbiology and Biotechnology 38 (2011) 1379-1390.

[146] Horizontal method for the enumeration of micro-organisms - Colony-count technique at $30^{\circ} \mathrm{C}$, ISO 4833, third edition 1.2.2003.

[147] Horwitz, W., Official Methods of Analysis of the Association of Official Analytical Chemists (1984), AOAC, Virginia, USA.

[148] SFS 5504. Determination of chemical oxygen demand (COD Cr) in water with the closed tube method. Oxidation with dichromate.

[149] Örså F., Holmbom B., A Convenient Method for the Determination of Wood Extractives in Papermaking Process Waters and Effluents, Journal of Pulp and Paper Science 20 (1994) J361-J366. 
[150] Patra, S., Munichandraiah, N., Electrochemical reduction of hydrogen peroxide on stainless steel, Journal of Chemical Sciences 121 (2009) 675-683.

[151] Qiang, Z., Chang, J.-H., Huang, C.-P., Electrochemical generation of hydrogen peroxide from dissolved oxygen in acidic solutions, Water Research 36 (2002) 85-94.

[152] Jeong, J., Kim, J.Y., Yoon, J., The role of reactive oxygen species in the electrochemical inactivation of microorganisms, Environmental Science and Technology 40 (2006) 6117-6122.

[153] Liang, W., Qu, J., Chen, L., Liu, H., Lei, P., Inactivation of Microcystis aeruginosa by continuous electrochemical cycling process in tube using $\mathrm{Ti} / \mathrm{RuO} 2$ electrodes, Environmental Science and Technology 39 (2005) 4633-4639.

[154] Raulio, M., Järn, M., Ahola, J., Peltonen, J., Rosenholm, J.B., Tervakangas, S., Kolehmainen, J., Ruokolainen, T., Narko, P., Salkinoja-Salonen, M., Microbe repelling coated stainless steel analyzed by field emission scanning electron microscopy and physicochemical methods, Journal of Industrial Microbiology \& Biotechnology 35 (2008) 751-760.

[155] Martinez-Huitle, C.A., Brillas, E., Electrochemical Alternatives for Drinking Water Disinfection, Angewandte Chemie International Edition 47 (2008) 1998-2005.

[156] Choi, J., Shim, S., Yoon, J., Design and operating parameters affecting an electrochlorination system, Journal of Industrial and Engineering Chemistry 19 (2013) 215-219.

[157] Mascia, M., Vacca, A., Palmas, S., Fixed bed reactors with three dimensional electrodes for electrochemical treatment of waters for disinfection, Chemical Engineering Journal 211-212 (2012) 479-487. 
[158] Kerwick, M.I., Reddy, S.M., Chamberlain, A.H.L., Holt, D.M., Electrochemical disinfection, an environmentally acceptable method of drinking water disinfection?, Electrochimica Acta 50 (2005) 5270-5277.

[159] Waterston, K., Bejan, D., Bunce, N.J., Electrochemical oxidation of sulfide ion at a borondoped diamond anode, Journal of Applied Electrochemistry 37 (2007) 367-373.

[160] Lawrence, J., Robinson, K.L., Lawrence, N.S., Electrochemical Determination of Sulfide at Various Carbon Substrates: A Comparative Study, Analytical Science 23 (2007) 673-676.

[161] Khansorthong, S., Hunsom, M., Remediation of wastewater from pulp and paper mill industry by the electrochemical technique, Chemical Engineering Journal 151 (2009) 228-234.

[162] Scialdone, O., Galia, A., Guarisco, C., Randazzo, S., Filardo, G., Electrochemical incineration of oxalic acid at boron doped diamond anodes: role of operative parameters, Electrochimica Acta 53 (2008) 2095-2108. 